\title{
The serine/threonine kinase Pim-2 is a transcriptionally regulated apoptotic inhibitor
}

\author{
Casey J. Fox, ${ }^{1,2}$ Peter S. Hammerman, ${ }^{1,2}$ Ryan M. Cinalli, ${ }^{1,2}$ Stephen R. Master, ${ }^{1,3}$ \\ Lewis A. Chodosh, ${ }^{1,2,3}$ and Craig B. Thompson ${ }^{1,2,3,4}$ \\ ${ }^{1}$ Abramson Family Cancer Research Institute, Philadelphia, Pennsylvania 19104, USA; ${ }^{2}$ Department of Cancer Biology and \\ ${ }^{3}$ Department of Medicine, University of Pennsylvania, Philadelphia, Pennsylvania 19104, USA
}

Growth factor withdrawal results in the termination of factor-dependent transcription. One transcript that declines rapidly following growth factor deprivation of hematopoietic cells is the serine/threonine kinase pim-2. When constitutively expressed, Pim-2 conferred long-term resistance to a variety of apoptotic stimuli including growth factor withdrawal and endogenous levels of Pim-2 contributed to growth factor-mediated apoptotic resistance. Pim-2 expression maintained cell size and mitochondrial potential independently of the PI3K/Akt/TOR pathway. Pim-2-dependent maintenance of cell size and survival correlated with its ability to maintain rapamycin-resistant phosphorylation of the translational repressor 4E-BP1 and phosphorylation of the BH3 protein BAD. These results establish Pim-2 as a direct link between growth factor-induced transcription and a novel, kinase-dependent pathway that promotes cell-autonomous survival.

[Keywords: Pim-2; TOR; Akt; transcriptional regulation; kinase]

Received April 17, 2003; revised version accepted June 2, 2003.

Growth factors promote cellular survival, growth, and proliferation via an intricate signal transduction cascade that results in the activation of transcription and translation. When withdrawn from growth factor, dependent cells undergo programmed cell death, or apoptosis. Growth factor signals directly support cell survival by increasing transcription of the pro-survival members of the Bcl-2 protein family, including Bcl- $\mathrm{x}_{\mathrm{L}}$ and $\mathrm{Bcl}-2$ (for review, see Cory and Adams 2002). Although their levels establish the apoptotic threshold of a cell, antiapoptotic Bcl-2 proteins have long half-lives and undergo relatively small changes in expression during the time frame in which growth factor withdrawal initiates apoptosis. Alternatively, growth factors promote cell survival by inducing a phosphorylation cascade that inhibits the activities of proapoptotic proteins. For example, mitogenic signals activate the serine/threonine kinase Akt, which then inactivates both the proapoptotic $\mathrm{BH} 3$ protein $\mathrm{BAD}$ and caspase 9 (for review, see Nicholson and Anderson 2002). Akt also phosphorylates members of the Forkhead family of transcriptional activators, thereby suppressing the Forkhead-dependent expression of additional death genes, such as FAS ligand and the BH3 protein BIM (for review, see Arden and Biggs 2002). Although the ability

${ }^{4}$ Corresponding author.

E-MAIL craig@mail.med.upenn.edu; FAX (215) 746-5511.

Article published online ahead of print. Article and publication date are at http://www.genesdev.org/cgi/doi/10.1101/gad.1105003. of Bcl-2 family proteins and Akt to confer growth factorindependent survival has been well established, it is unclear whether additional cell survival pathways exist that can dynamically respond to acute changes in growth factor-dependent transcription.

Many of the acutely regulated transcriptional targets of growth factor signals contribute to cell growth and proliferation rather than cell survival. For example, the transcription factors c-Myc and c-Fos encode mRNAs and proteins with short half-lives and are dynamically regulated in response to extracellular signals (for review, see Tulchinsky 2000; Hoffman et al. 2002). Dysregulated expression of c-Myc or c-Fos contributes to malignant transformation and has been observed in multiple tumor types. Paradoxically, however, the ectopic expression of either gene predisposes cells to apoptosis when the cells are deprived of exogenous growth factors (for review, see Pelengaris et al. 2002). This observation has led to the hypothesis that the growth factor-induced transcriptional program that initiates cell proliferation may also predispose cells to death in the absence of the compensatory action of prosurvival pathways.

In an effort to identify the acute transcriptional targets that might contribute to cell survival, we performed an oligonucleotide microarray-based analysis of RNA isolated from the murine interleukin-3 (IL-3)-dependent, pro-B cell line FL5.12. The serine/threonine kinase pim-2 was the most down-regulated of 9500 genes and expressed sequence tags (ESTs) following growth factor 
Fox et al.

withdrawal. Pim-2 was first identified as a frequent site of proviral insertion in the lymphomas that arise following infection with the Murine Moloney Leukemia virus (van der Lugt et al. 1995; Allen et al. 1997). Pim-2 has a well-documented role in oncogenesis (for review, see Allen and Berns 1996) and the coexpression of Pim-2 and c-Myc transgenes induces malignant transformation in vivo (Allen et al. 1997). In patients, dysregulated Pim-2 expression is observed in prostate cancer (Dhanasekaran et al. 2001; Neill and Kelsell 2001), lymphoma (Yoshida et al. 1999), leukemia (Amson et al. 1989), and multiple myeloma (Claudio et al. 2002). These features prompted us to investigate Pim-2 as a potential mediator of growth factor-regulated cell survival.

IL-3 availability dynamically regulated Pim-2 at both the RNA and protein levels. Endogenous Pim-2 was catalytically active in multiple cell lines and both in vitro translated and in vivo transfected Pim-2 were kinase active. The dynamic regulation of a kinase by growth factor-dependent transcription seemed a paradoxical result, warranting further investigation. We found that the constitutive expression of catalytically-active, but not kinase dead, Pim-2 conferred long-term resistance to apoptosis in the absence of IL-3 or when cells were treated with cytotoxic drugs. The biological effects of a Pim-2 transgene were compared with two well-characterized antiapoptotic genes, Bcl- $\mathrm{x}_{\mathrm{L}}$ and Akt. The antiapoptotic properties of Pim-2 were distinct from Bcl- $\mathrm{x}_{\mathrm{L}}$. Rather, Pim-2 recapitulated the phenotypic effects of Akt by promoting cell autonomous maintenance of cell size, glycolysis, and mitochondrial potential in the absence of growth factor. However, Pim-2 did not affect Akt activity and Pim-2-dependent survival was resistant to multiple inhibitors of the PI3K/Akt/TOR pathway. IL-3 induction of both endogenous Pim-2 expression and Akt activation resulted in activation of two distinct antiapoptotic pathways that appeared to converge on an overlapping set of effector molecules to maintain cell survival and size.

\section{Results}

\section{Dynamic regulation of Pim-2 expression}

To identify genes whose transcription was acutely regulated by growth factor availability, an oligonucleotidebased microarray analysis of RNA isolated from FL5.12 cells before and after IL-3 withdrawal was performed. FL5.12 is a murine, nontransformed, pro-B cell line dependent on IL-3 for survival, growth, and proliferation (Algate et al. 1994). FL5.12 cells initiate apoptosis following growth factor withdrawal and $<1 \%$ remain viable after $3 \mathrm{~d}$ of IL-3 deprivation. After $12 \mathrm{~h}$ of deprivation, cells have not yet committed to apoptosis as cytokine re-addition at this time rescues cells from death /data not shown). RNA was prepared from cells withdrawn from IL-3 for 0, 6, 9 or $12 \mathrm{~h}$ and hybridized to the Affymetrix murine $11 \mathrm{~K}$ oligonucleotide microarrays representing 9500 unique genes and ESTs. Data from three independent experiments were averaged and pairwise analyses performed to identify genes whose expression changed following IL-3 removal. The serine/threonine kinase pim-2 was the most down-regulated of 9500 genes and ESTs between 0 and $12 \mathrm{~h}$ of IL-3 withdrawal $(p<0.0005)$. This change in pim-2 expression was confirmed via Northern blot. The pim-2 transcript dropped within $6 \mathrm{~h}$ of cytokine withdrawal and was undetectable at $12 \mathrm{~h}$ (Fig. 1A). A subsequent kinetic analysis showed that the decline in pim-2 transcription preceded the commitment to cell death. Pim-2 mRNA was absent when cells were deprived of IL-3 for $6 \mathrm{~h}$ and then recovered fully when cytokine was added back for an additional $6 \mathrm{~h}$ (Fig. 1A).

The acute, growth factor-dependent regulation of a serine/threonine kinase seemed an unusual finding. A

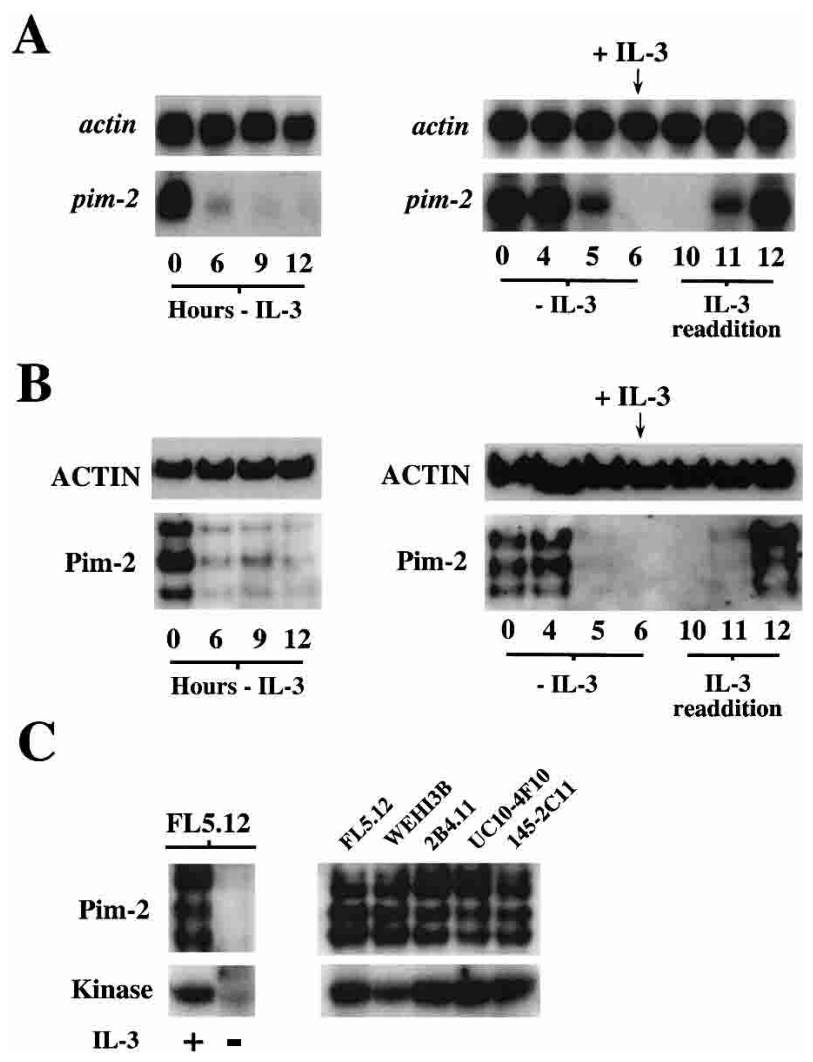

Figure 1. IL-3 regulates Pim-2 RNA and protein expression. (A) RNA samples were isolated from FL5.12 cells at $0,6,9$, or $12 \mathrm{~h}$ post-IL-3 withdrawal and screened for pim- 2 and $\beta$-actin expression by Northern blot (left panels). RNA was also prepared from IL-3-deprived (-IL-3) cells at the indicated time points (right panels). After $6 \mathrm{~h}$ of IL-3 deprivation, IL-3 was added back (+IL-3) and RNA prepared 4, 5, and $6 \mathrm{~h}$ later $(10,11$, and $12 \mathrm{~h}$ after the start of the experiment). (B) Western blots of total cell lysates prepared over the time courses described in $A$ were sequentially probed for ACTIN and Pim- 2 proteins. $(C)$ Pim- 2 was immunoprecipitated from FL5.12 cells growing exponentially in IL-3 (+), or after $12 \mathrm{~h}$ of IL-3 and serum withdrawal (-). Half of each sample was used in a Pim-2 Western blot (top panel) and the remainder used in a kinase assay with histone $\mathrm{H} 1$ as a substrate (bottom panel). A no-substrate reaction was used as a negative control (data not shown). Pim-2 expression and kinase activity were similarly examined in cycling FL5.12, WEHI3B, 2B4.11, UC10-4F10, and 145-2C11 cells (right panels). 
search of available microarray databases indicated that pim-2 is regulated similarly in other cell types. Diverse proliferative signals, including mitogens, IL-1, IL-5, and antigen receptor ligation induce similarly dynamic changes in pim-2 expression in both human and murine hematopoietic cells (Li et al. 2001; Mikovits et al. 2001; Temple et al. 2001; Claudio et al. 2002; Muschen et al. 2002; Xu et al. 2002). These data argue that Pim-2 is a target of a variety of growth factor-dependent transcriptional responses.

Western blots of lysates from control and IL-3-deprived FL5.12 cells showed that the kinetics of Pim-2 protein expression closely mimicked that of the RNA transcript (Fig. 1B). Pim-2 contains three imperfect Kozak consensus sites that independently direct translational initiation, so that a single transcript yields three proteins of 34,37 , and $40 \mathrm{kD}$ that differ at their $\mathrm{N}$ termini but contain identical catalytic sites (Breuer et al. 1989). The three Pim-2 isomers were present at stoichiometric levels in control cells and declined concomitantly after IL-3 removal (Fig. 1B). Endogenous Pim-2 purified from FL5.12 cells growing exponentially in IL-3 demonstrated considerable kinase activity against an exogenous substrate (Fig. 1C). After $12 \mathrm{~h}$ of IL-3 deprivation, Pim-2 protein and kinase activity were undetectable. Endogenous kinase active Pim-2 protein was also readily detected in other murine cell lines, including the myeloid leukemia line WEHI3B, the $\mathrm{T}$ cell hybridoma $2 \mathrm{~B} 4.11$ and the B cell hybridoma lines UC10-4F10 and 145-2C11.

\section{Expressed Pim-2 is kinase active}

IL-3 availability tightly regulated Pim-2 RNA and protein expression. Because the Pim-2 sequence lacks known regulatory motifs, one possibility is that Pim-2 catalytic function may be regulated primarily by expression as opposed to the posttranscriptional mechanisms that modulate the activities of many other kinases. To investigate this possibility, full-length murine Pim-2 transgenes were constructed and stable FL5.12 cell lines were generated. Transgenic introduction of a wild-type, murine Pim-2 cDNA (Pim-2-L1; Breuer et al. 1989) resulted in the expression of both the 40- and 37-kD Pim-2 isoforms (Fig. 2A). Substituting a consensus Kozak sequence at the translational start site (Pim-2-L1M, hereafter referred to as Pim-2) resulted in exclusive expression of the $40 \mathrm{kD}$ isoform. A Pim-2 transgene was also made in which the lysine residue at position 121 was replaced with methionine (Pim-2-KD). The latter mutation disrupts the formation of a conserved ATP-binding pocket critical to the catalytic function of most serine/ threonine kinases (Huse and Kuriyan 2002). Transfected Pim-2-L1 and Pim-2 were kinase-active when purified from FL5.12 cells grown for $12 \mathrm{~h}$ in the absence of IL-3 and serum. In contrast, Pim-2-KD showed no kinase activity in excess of the empty vector control. Both the pattern of Pim-2 isoform expression and kinase activity were recapitulated when the same constructs were translated in vitro in a cell-free system (Fig. 2A). Thus, expressed Pim-2 appears to be enzymatically active in the
A

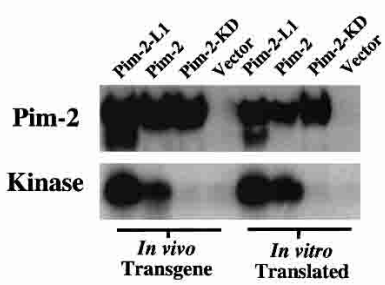

C

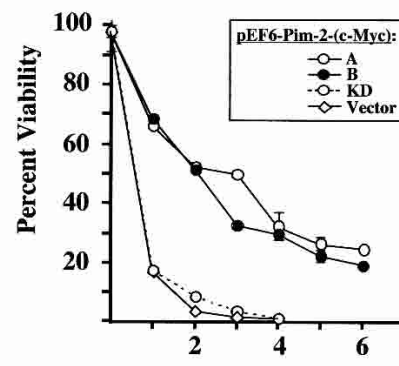

B
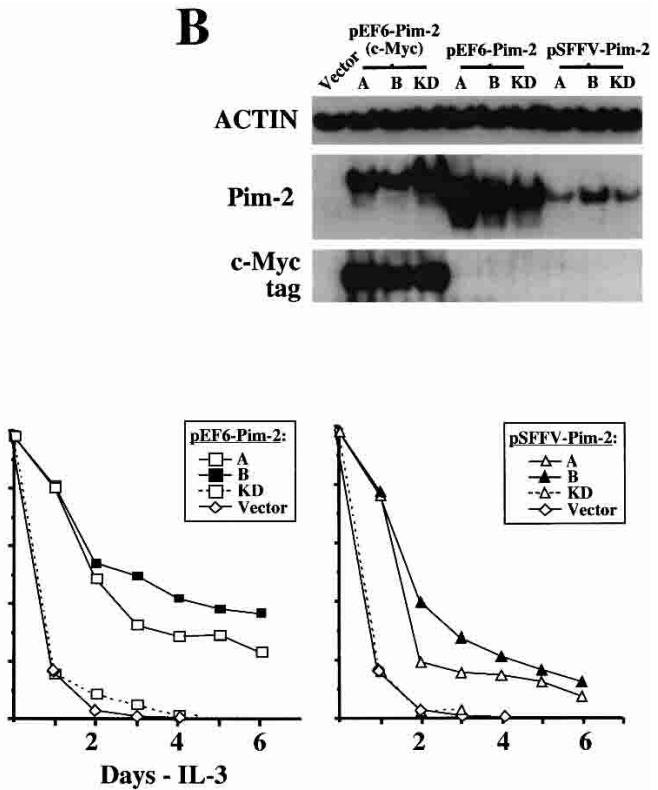

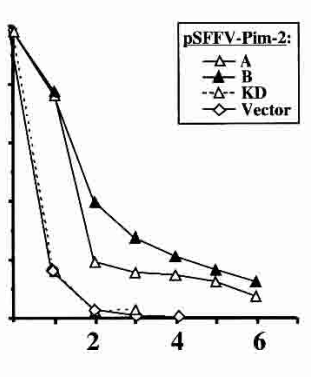

Figure 2. Pim-2 prevents IL-3 withdrawal-induced apoptosis. (A) Pim-2 Western blots and kinase assays are shown. Stable FL5.12 cell lines were generated constitutively expressing Pim-2-L1, Pim2 , or Pim-2-KD constructs or an empty vector control. IL-3-independent expression and kinase activity of transgenic Pim-2 is shown in vivo following a 12 -h period of IL-3 and serum withdrawal, a time point at which endogenous Pim-2 is undetectable (see Fig. 1C). Pim-2 expression and kinase activity using the same constructs translated in vitro is also shown. (B) Lysates were prepared from stable FL5.12 cell lines and compared for ACTIN, Pim-2, and c-Myc epitope expression. Pim-2 was constitutively expressed in cells using two vectors with different promoters (pEF6 and pSFFV). A C-terminal $\mathrm{c}-\mathrm{Myc}$ epitope-tagged version (pEF6-Pim2-c-Myc) was also prepared. Two stable lines (A and B) are shown in each case. Stable lines expressing Pim-2-KD were also made. Control lines were transfected with empty vector. $(C)$ Percent viability versus days (-) IL-3 is shown. The Pim-2 clones described in $B$ showed prolonged protection from IL-3 withdrawal-induced apoptosis. Cells expressing kinase-dead Pim-2 (Pim-2-KD) were not protected from IL-3 withdrawal-induced apoptosis and died with kinetics similar to control. $(\diamond)$ pEF6 empty vector; $(\bigcirc$, solid

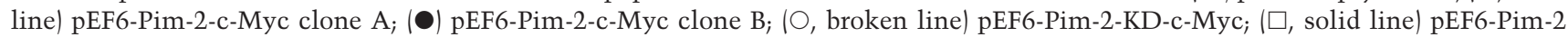
clone $\mathrm{A}_{;}(\mathbf{\square})$ pEF6-Pim-2 clone $\mathrm{B} ;\left(\square\right.$, broken line) pEF6-Pim-2-KD; $\left(\triangle\right.$, solid line) pSFFV-Pim-2 clone $\mathrm{A}_{;}(\mathbf{\Delta})$ pSFFV-Pim-2 clone $\mathrm{B}_{;}(\triangle$, broken line) pSFFV-Pim-2-KD. Data are presented as the mean \pm S.D. of triplicate samples and are representative of three independent experiments. 
Fox et al.

absence of cytokine or serum-derived mitogenic signals. Under all conditions studied there was close association between protein levels and kinase activity.

\section{Constitutive expression of Pim-2 confers apoptotic resistance}

We readily obtained stable clones that showed a broad range of Pim-2 expression (Fig. 2B). Ectopic Pim-2 expression appeared to have no effect on mean cell size, cell cycle distribution, or growth rate in the presence of IL-3 and each of the lines remained IL-3-dependent for growth and proliferation (data not shown). However, one clear phenotype emerged. The constitutive expression of either Pim-2-L1 or Pim-2 conferred dose-dependent resistance to apoptosis following growth factor withdrawal (Fig. 2C; data not shown). Only at the very highest levels of Pim-2 expression did we fail to detect dose-dependent antiapoptotic activity, suggesting that the antiapoptotic effects of Pim-2 can be saturated. Even as late as $6 \mathrm{~d}$ after IL-3 removal, $40 \%$ of cells expressing high levels of Pim-2 remained viable. This time point was well past the point at which control cells could be rescued by IL-3 re-addition, as they were $<1 \%$ viable $3 \mathrm{~d}$ after growth factor withdrawal. The survival promoting effect of Pim-2 was dependent on intrinsic catalytic activity, as the kinetics of death in cells expressing kinase-dead Pim2 -KD recapitulated that of the vector controls. Thus, Pim-2 kinase functions as an antiapoptotic molecule.

Pim-2 conferred the resistance to other apoptosis-inducing pathways in addition to growth factor withdrawal. Staurosporine, a broad inhibitor of multiple kinases, including protein kinases $\mathrm{A}, \mathrm{B}$, and $\mathrm{C}$, induces programmed cell death in a wide variety of cell lines (for review, see Omura et al. 1995). Thapsigargin induces apoptosis by inhibiting the endoplasmic reticular $\mathrm{Ca}^{2+}$ ATPase (for review, see Treiman et al. 1998). Staurosporine $(50 \mathrm{nM})$, or $5 \mu \mathrm{M}$ of thapsigargin, killed the majority of control cells within $24 \mathrm{~h}$ (Fig. 3A). In contrast, $\sim 60 \%$ of cells expressing the Pim-2 transgene survived these treatments. Indeed, the Pim-2-dependent resistance to chemically induced apoptosis was comparable to that conferred by the antiapoptotic gene $\mathrm{Bcl}-\mathrm{x}_{\mathrm{L}}$, as $\mathrm{Bcl}-\mathrm{x}_{\mathrm{L}}$-expressing FL5.12 cells were also resistant to these treatments. Similar results were evident in the Pim-2 and Bcl- $\mathrm{x}_{\mathrm{L}}$ lines treated with the DNA damaging agent etoposide, or the topoisomerase-inhibitor doxyrubicin (data not shown). Thus, constitutive Pim-2 expression can affect multiple pathways that induce apoptosis.

The antiapoptotic effects of Pim-2 are not limited to FL5.12 cells. Cell lines stably expressing Pim-2 were also generated in WEHI3B cells and the human T lymphoma Jurkat cell line, as well as human nonhematopoietic colon carcinoma HeLa cells that do not express endogenous Pim-2 RNA (data not shown). As shown in Figure $3 \mathrm{~B}$, Pim-2 provided substantial resistance to both staurosporine and thapsigargin-induced apoptosis in each of the three cell lines. Thus, the antiapoptotic effects of Pim-2 were recapitulated in hematopoietic and nonhematopoietic cell lines from both mice and humans, sug-

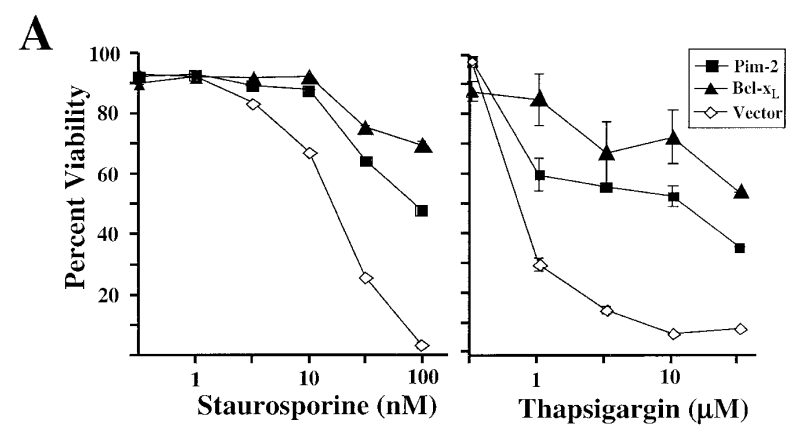

B
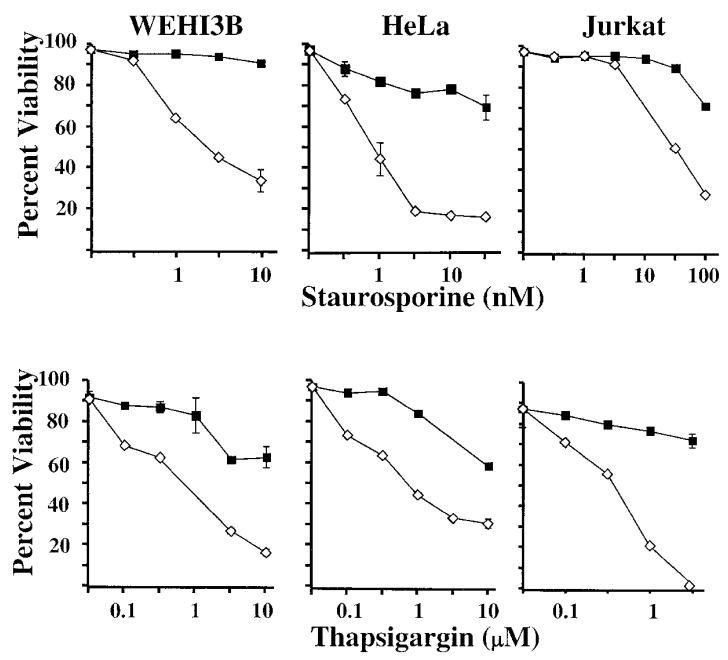

Figure 3. Pim-2 prevents drug-induced apoptosis. (A) Percent viability was assessed in Pim-2 (ם), Bcl- $\mathrm{x}_{\mathrm{L}}(\mathbf{\Delta})$, and vector control $(\diamond)$ FL5.12 cells treated with the kinase inhibitor staurosporine or with the $\mathrm{Ca}^{2+}$-ATPase inhibitor thapsigargin. Data are presented as the mean \pm S.D. of triplicate samples and are representative of three independent experiments. $(B)$ Percent viability was assessed in $\operatorname{Pim}-2(\boldsymbol{\square})$ and vector control $(\diamond)$ WEHI3B, HeLa, and Jurkat cells treated with staurosporine or thapsigargin. Data are presented as the mean \pm S.D. of triplicate samples and are representative of three independent experiments.

gesting that the Pim-2 may regulate cell survival in a generalized fashion.

\section{Pim-2 confers long-term growth factor-independent survival}

Few genes have been described that can provide longterm resistance to apoptosis. Two pathways have been implicated in mediating prolonged IL-3-independent cell survival. The first is regulated by the Bcl-2 family of proteins, and the second involves maintaining the catalytic activity of Akt. We compared the phenotypic effects of ectopic Pim-2 expression with a Bcl- $\mathrm{x}_{\mathrm{L}}$ transgene and an Akt construct targeted to the plasma membrane by a c-SRC myristoylation consensus site (mAkt), thus rendering it constitutively active.

Pim-2, Bcl- $\mathrm{x}_{\mathrm{L}}$ and mAkt were constitutively expressed in FL5.12 cells (Fig. 4A) that were deprived of IL-3 for 3 
wk. Over the first $3 \mathrm{~d}$ of IL-3 deprivation, the vector control line exhibited a characteristic decline in both viability (Fig. 4B) and cell size (Fig. 4C). Ectopic Pim-2 expression provided substantial and long-term resistance to growth factor withdrawal-induced apoptosis. The viability of the Pim-2 line plateaued at $35 \%-40 \%$ at $4 \mathrm{~d}$ post-IL-3 withdrawal and then did not change significantly over the next $2 \mathrm{wk}$ (Fig. 4B). Even as late as $18 \mathrm{~d}$ after IL-3 removal, over one third of the Pim-2-expressors remained viable. The mean cell size of the Pim-2-expressing cells declined steadily between 0 and $4 \mathrm{~d}$ of growth factor deprivation and then stabilized for the remainder of the experiment (Fig. 4C). The long-term ability of Pim-2 to maintain cell viability in the absence of
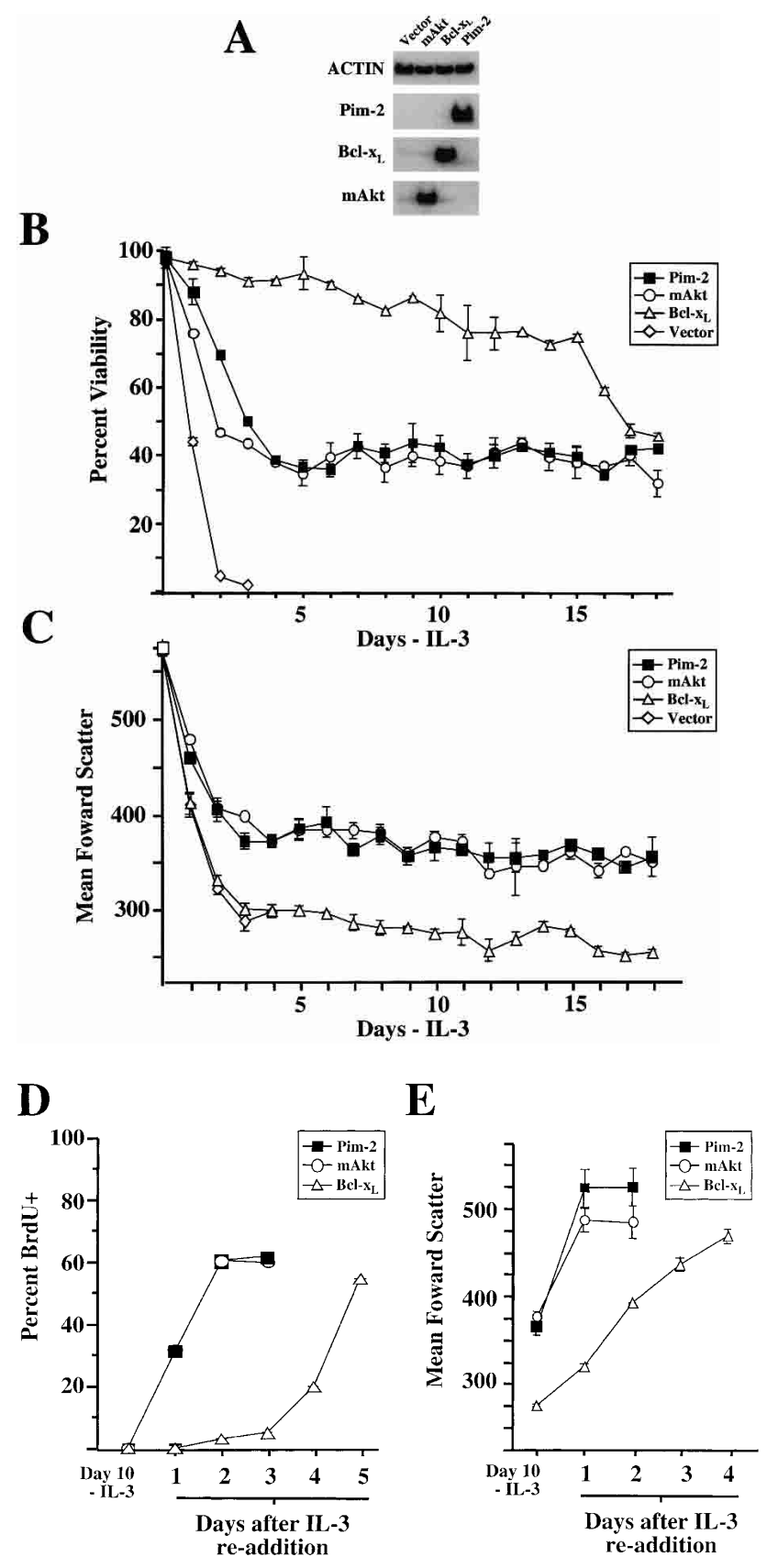

IL-3 was not due to cell proliferation, as daily analysis showed that $>99 \%$ of viable Pim-2 cells remained arrested in the $G_{1}(2 N)$ phase of the cell cycle between 4 and $18 \mathrm{~d}$ (data not shown; Fig. 4D). The phenotypic effects of Pim-2 with respect to both cell viability and size in the absence of growth factor were recapitulated in cells expressing the mAkt transgene (Fig. 4). In contrast, the $\mathrm{Bcl}-\mathrm{x}_{\mathrm{L}}$ line remained $>90 \%$ viable until $1 \mathrm{wk}$ after IL-3 removal. Bcl- $\mathrm{x}_{\mathrm{L}}$-expressing cells did demonstrate a progressive decline in viability beginning after $2 \mathrm{wk}$ of IL-3 deprivation. Over this time, the $\mathrm{Bcl}-\mathrm{x}_{\mathrm{L}}$ line atrophied to a significantly greater extent than the Pim-2 cells. By the 18-d time point, the percentage of viable cells was similar in all of the cell lines. The results did

Figure 4. Pim-2 maintains the survival and size of growth factor-deprived cells. (A) Western blots of Pim-2, Bcl- $\mathrm{x}_{\mathrm{L}}$, phosphoSer 473-Akt (mAkt) and ACTIN are shown using lysates from FL5.12 lines stably expressing Pim-2, mAkt, and Bcl- $\mathrm{x}_{\mathrm{L}}$ transgenes. Empty vector was used a negative control. $(B)$ Percent viability was assessed daily for $18 \mathrm{~d}$ following IL-3 deprivation. (ם) Pim-2; $(\bigcirc) \mathrm{mAkt}_{;}(\triangle) \mathrm{Bcl}-\mathrm{x}_{\mathrm{L} j}(\diamond)$ vector control. The data are presented as the mean \pm S.D. of triplicate samples and are representative of five independent experiments. $(C)$ The mean forward scatter (as an indicator of cell size) of the cells in $B$ are plotted versus days post-IL-3 withdrawal. (ם) Pim-2; (O) mAkt; $(\triangle) \mathrm{Bcl}-\mathrm{x}_{\mathrm{L}} ;(\diamond)$ vector control. Data are presented as the mean \pm S.D. of triplicate samples and are representative of five independent experiments. $(D)$ The percent of $\mathrm{BrdU}^{+}$cells versus days post-IL-3 re-addition is shown. At day 10 post-IL-3 withdrawal, the percentage of live cells in cycle was assessed by measuring BrdU incorporation. IL-3 was then re-added to the cultures and BrdU incorporation measured daily. (口) Pim-2; (O) mAkt; $(\triangle) \mathrm{Bcl}-\mathrm{x}_{\mathrm{L}}$. Vector control cells were $<1 \%$ viable after $3 \mathrm{~d}$ of IL-3 withdrawal (see Fig. 2C) and were not analyzed. The mean \pm S.D. of triplicate samples are graphed and are representative of two independent experiments. $(E)$ The mean forward scatter of the cells analyzed in $D$ versus days after IL-3 re-addition are shown and represent the mean \pm S.D. of triplicate

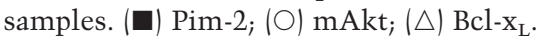


Fox et al.

not appear to be due to clonal selection, as these kinetics were recapitulated when the lines were rescued by cytokine re-addition at day 18 and then used for subsequent IL-3 withdrawal experiments.

Pim-2-protected cells recover rapidly from growth factor withdrawal

After $10 \mathrm{~d}$ of IL-3 deprivation $<1 \%$ of viable Pim-2-, mAkt-, or Bcl- $\mathrm{x}_{\mathrm{L}}$-expressing cells remained in the cell cycle as measured by bromodeoxyuridine (BrdU) incorporation (Fig. 4D). Within $24 \mathrm{~h}$ of IL-3 re-addition, 30\% of the Pim-2-expressing cells had re-entered the cell cycle and by $48 \mathrm{~h} 60 \%$ of cells were BrdU-positive. IL-3 re-addition also resulted in a rapid increase in the size of Pim-2 cells over this time (Fig. 4E). The kinetics of cell cycle re-entry and cell growth following cytokine re-addition were indistinguishable when the Pim-2 line was compared with the mAkt-expressing cells. In contrast, $\mathrm{Bcl}-\mathrm{x}_{\mathrm{L}}$-expressing cells did not recover as quickly, requiring $5 \mathrm{~d}$ of IL-3 stimulation to fully re-enter the cell cycle (Fig. 4D). However, Bcl- $\mathrm{x}_{\mathrm{L}}$ cells did respond to cytokine within the first $24 \mathrm{~h}$ of IL-3 re-addition by increasing cell size, although it took $5 \mathrm{~d}$ to reach the size characteristic of exponentially growing cells (Fig. 4E).

\section{Pim-2 maintains mitochondrial potential}

The mitochondrial cell death pathway appears to be activated when mitochondria lose the ability to maintain inner membrane potential, resulting in the release of proapoptotic proteins into the cytosol. Growth factordependent cells display a progressive decline in mitochondrial potential $(\Delta \psi \mathrm{m})$ following growth factor withdrawal (Plas et al. 2001). We next examined the $\Delta \psi \mathrm{m}$ of the Pim-2, mAkt, and Bcl- $\mathrm{x}_{\mathrm{L}}$ lines following IL-3 withdrawal using the mitochondrial membrane potentiometric dye tetramethylrhodamine ester (TMRE). In the presence of IL-3, FL5.12 cells showed bright TMRE fluorescence indicative of healthy mitochondria (Fig. 5A, left panels). Pim-2-protected cells maintained a robust mitochondrial potential after $6 \mathrm{~d}$ of IL-3 withdrawal (Fig. 5A, right panels), as did the mAkt expressors. In contrast, $\Delta \psi \mathrm{m}$ had declined in Bcl- $\mathrm{x}_{\mathrm{L}}$-expressing cells after $6 \mathrm{~d}$ of growth factor deprivation (Fig. 5A) despite the minimal change in their viability (Fig. 4B). The latter observation is consistent with published reports that Bcl- $\mathrm{X}_{\mathrm{L}}$ confers the resistance to apoptosis without preventing the decline in cellular metabolism that accompanies growth factor withdrawal. In contrast, mAkt has been reported to maintain $\Delta \psi \mathrm{m}$ by directly stimulating glucose uptake, glycolytic rate, and NADH production in the absence of growth factor (Plas et al. 2001). The Pim-2-dependent maintenance of both cell size and mitochondrial potential suggests that ectopic Pim-2 kinase may also stimulate cellular metabolism in the absence of IL-3. The ability of a Pim-2 transgene to maintain a high rate of growth factor-independent glycolysis was next assessed. The Pim-2 line exhibited considerable glycolysis after $6 \mathrm{~d}$ of
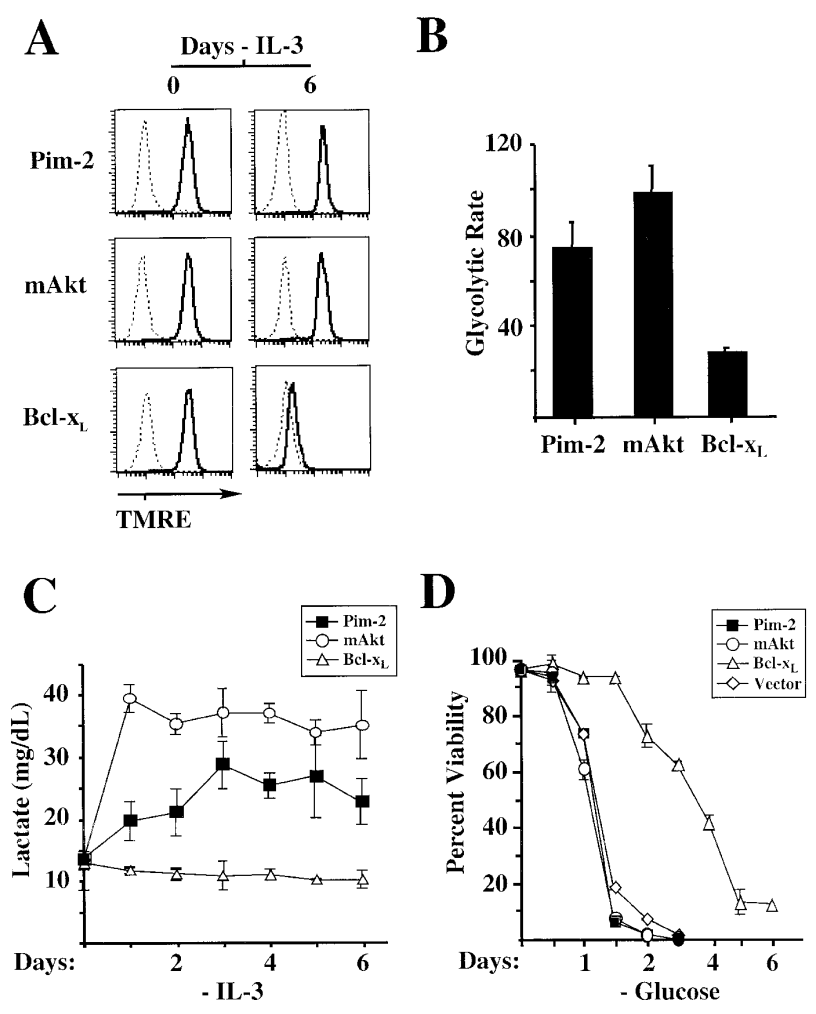

Figure 5. Pim-2 maintains mitochondrial potential and glycolytic metabolism in growth factor-deprived cells. (A) IL-3 was withdrawn from the Pim-2-, mAkt-, and Bcl- $\mathrm{x}_{\mathrm{L}}$-expressing lines for 0 or $6 \mathrm{~d}$ and mitochondrial potential assessed in live cells by TMRE staining (solid lines). As a negative control, the mitochondrial potential was collapsed in each population by the co-addition of CCCP (broken lines). The data are representative of five independent experiments. $(B)$ The glycolytic rate (millimoles glucose consumed per hour by 1 million live cells) was measured in Pim-2-, mAkt-, and Bcl- $\mathrm{x}_{\mathrm{L}}$-expressing cells after $6 \mathrm{~d}$ of IL-3 withdrawal. The data are presented as the mean \pm S.D. of triplicate determinations and are representative of two independent experiments. $(C)$ The lactate concentration $(\mathrm{mg} / \mathrm{dL})$ in the cell culture supernatants was measured as a function of days -IL-3. (回) Pim-2; (O) mAkt; $(\triangle)$ Bcl- $\mathrm{x}_{\mathrm{L}}$. The data are presented as the mean \pm S.D. of triplicate samples and are representative of three independent experiments. $(A-C)$ Empty vector control cells were dead within $3 \mathrm{~d}$ of IL-3 withdrawal (see Fig. 2C) and were not measured. $(D)$ Percent viability as a function of days following glucose reduction is shown. The Pim-2 (ם), mAkt (O), $\mathrm{Bcl}-\mathrm{x}_{\mathrm{L}}(\triangle)$, and vector control $(\diamond)$ lines were washed and resuspended in RPMI containing IL-3 and $20 \mu \mathrm{M}$ glucose (1:500 standard concentration) and viability assessed daily by PI exclusion for $6 \mathrm{~d}$. The data are presented as the mean \pm S.D. of triplicate determinations and are representative of three independent experiments.

IL-3 deprivation (Fig. 5B) and maintained a high glycolytic rate $(\sim 70$ mmoles of glucose consumed per hour by 1 million live cells). These features were reminiscent of the effects of the mAkt transgene, a known regulator of this metabolic pathway. In contrast, the glycolytic rate was significantly lower in Bcl- $\mathrm{x}_{\mathrm{L}}$-protected cells in the absence of IL-3 (Fig. 5B). Constitutive Pim-2 expression did more than simply allow cells to maintain the homeo- 
static levels of glucose uptake that are required for bioenergetics and replacement biosynthesis. The majority of glucose taken up by the Pim-2 line was converted into lactate and secreted into the culture supernatant (Fig. 5C). In contrast, Bcl- $\mathrm{x}_{\mathrm{L}}$-expressing cells fully oxidized the small amount of glucose they consumed.

\section{Pim-2 survival is glucose-dependent}

The above data suggest that Pim-2 may maintain mitochondrial potential by promoting the uptake of nutrients, such as glucose, in a cytokine-independent manner. Viability was next assessed in the Pim-2, mAkt, Bcl- $\mathrm{x}_{\mathrm{L}}$, and control lines after the glucose concentration in the culture supernatant was reduced 1:500 in the presence of IL-3. Pim-2- and mAkt-expressing and control cells rapidly initiated apoptosis and were $<1 \%$ viable after $2 \mathrm{~d}$ of glucose reduction (Fig. 5D), whereas ectopic Bcl- $\mathrm{x}_{\mathrm{L}}$ expression maintained long-term viability. Thus, like Akt, Pim-2-mediated cell survival is dependent on an extracellular source of glucose.

\section{Pim-2 function is distinct from Akt}

The phenotypic similarity of Pim-2- and mAkt-expressing cells suggests that Pim- 2 may function through the Akt pathway, either by affecting Akt activation or by influencing its downstream targets. To assess this possibility, lysates were prepared from $\mathrm{Bcl}-\mathrm{x}_{\mathrm{L}^{-}}, \mathrm{Pim}-2-$, and mAkt-expressing and control cells in the presence and absence of IL-3. In each of the lines, transgene expression was unaffected by IL-3 withdrawal and re-addition. The IL-3-dependent regulation of endogenous Pim-2 expression in the $\mathrm{Bcl}-\mathrm{x}_{\mathrm{L}}$ - and mAkt-expressing lines was identical to that of vector control at both the RNA and protein levels (data not shown). In the Pim-2 cells, a period of $12 \mathrm{~h}$ of IL-3 withdrawal caused an acute reduction in the activation status of endogenous Akt, as measured by its phosphorylation at residues Ser 473 (S-473) and Thr 308 (T-308), both of which are required for optimal Akt activity (Fig. 6A). Akt phosphorylation was re-established in growth factor-deprived Pim-2 cells within $12 \mathrm{~h}$ of IL-3 re-addition. The levels of total Akt remained unchanged. Phosphorylation of the Akt substrate GSK3 $\beta$ also changed in response to IL-3 availability. In contrast, expression of the mAkt transgene maintained S-473 and T-308 phosphorylation and GSK3 $\beta$ phosphorylation in the absence of IL-3 (Fig. 6A, right panels), a feature consistent with the constitutive activation of this pathway. Thus, Pim-2 appeared to mirror the phenotypic effects of Akt without directly affecting its expression, phosphorylation status, or activity.

\section{Pim-2 antiapoptotic function does not depend on mediators of PI3K signal transduction}

The expression level of Pim-2 is a major mechanism to control its kinase activity. In contrast, Akt represents the more common paradigm in which kinase activity is
$\mathbf{A}$

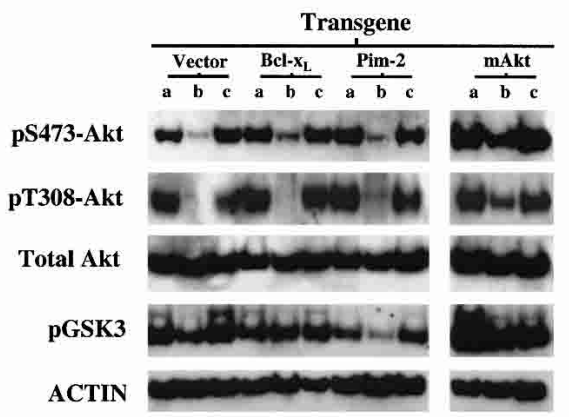

B

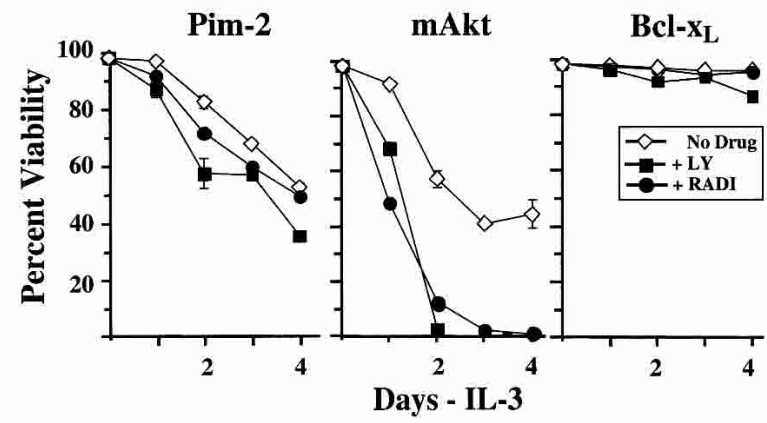

Figure 6. Pim-2 functions independently of the Akt pathway. (A) Western blots were serially stripped and reprobed for phospho-Ser 473-Akt (pS473-Akt), phospho-Thr 308-Akt (pT308Akt), total Akt, phospho-Ser 9-GSK3 $\beta$ (pGSK3), and ACTIN. Lysates were prepared from vector control, $\mathrm{Bcl}-\mathrm{x}_{\mathrm{L}}, \mathrm{Pim}-2$, and mAkt cells at 0 (lane $a$ ) and $12 \mathrm{~h}$ (lane $b$ ) post-IL-3 withdrawal, and from cells to which IL-3 had been added back to the culture for $12 \mathrm{~h}$ immediately following the 12-h IL-3 withdrawal period (lane $c) .(B)$ The Pim-2, Bcl- $\mathrm{x}_{\mathrm{L}}$ and $\mathrm{mAkt}$ lines were withdrawn from IL-3 in the presence of no drug ( $\diamond), 5 \mu$ M LY294002 (+LY; $\mathbf{\square})$, or $0.2 \mu \mathrm{M}$ radicicol (+RADI; $\bullet$ ), and viability assessed daily for the next $4 \mathrm{~d}$. Vector control cells died with rapid kinetics following IL-3 withdrawal independent of inhibitor addition (see Fig. 2C for representative data). The figure data are the mean \pm S.D. of triplicate samples and are representative of five independent experiments.

modulated posttranslationally. For example, Akt is activated by PDK-1 and PDK-2, two enzymes downstream of PI3K (for review, see Nicholson and Anderson 2002) and Akt requires the HSP-90 chaperone to maintain its catalytic site in an active conformation (Basso et al. 2002). To determine if the antiapoptotic effects of Pim-2 are functionally separable from Akt, we next performed a series of experiments using drugs that target Akt or its upstream regulators. Following treatment with the PI3K inhibitor LY294002 (Vlahos et al. 1994) or radicicol, an inhibitor of HSP-90 (Schulte et al. 1999), the ability of Pim-2 to support growth factor-independent survival was minimally affected (Fig. 6B). Similarly, Bcl- $\mathrm{x}_{\mathrm{L}}$-dependent cell survival in the absence of IL-3 was refractory to both LY294002 and radicicol (Fig. 6B). In contrast, both treatments exerted a profound negative effect on mAkt-dependent survival. For example, whereas untreated mAkt-expressing cells were $40 \%$ viable after $3 \mathrm{~d}$ 
of IL-3 withdrawal, <1\% of cells treated with LY294002 or radicicol were alive at this time. Similar results were evident in cells treated with the PI3K inhibitor wortmannin, the Akt-inhibiting PI analog 1L-6-Hydroxymethyl-chiro-inositol 2-(R)-2-O-methyl-3-O-octadecylcarbonate (Covey et al. 2000), or geldanamycin, an HSP-90 inhibitor chemically distinct from radicicol, as Bcl- $\mathrm{x}_{\mathrm{L}^{-}}$and Pim-2-expressing cells were minimally affected and the drugs abrogated the protective effect of mAkt (data not shown). Thus, Pim-2 can maintain survival independently of the activities of PI3K, HSP-90, and Akt.

TOR inhibition fails to suppress the antiapoptotic function of Pim-2

A previous report showed that mAkt-dependent survival requires the target of rapamycin (TOR) pathway, as rapamycin treatment reverses the ability of Akt to promote growth factor-independent survival (Edinger and Thompson 2002). Akt may therefore promote cell survival by stimulating protein translation in a TOR-dependent manner. We next examined the rapamycin sensitivity of Pim-2 function. As an alternative means to suppress translation, cells were also treated with the protein synthesis inhibitor cycloheximide. Rapamycin had no effect on the growth factor-independent survival of Pim-2-expressing cells (Fig. 7A). Approximately $40 \%$ of Pim-2expressing cells were viable after $3 \mathrm{~d}$ of IL-3 withdrawal in the presence or absence of rapamycin, suggesting that Pim-2 functions independently of the TOR pathway. In contrast, IL-3-deprived Pim-2 cells were sensitive to cycloheximide and were $<1 \%$ viable after $3 \mathrm{~d}$ of IL-3 deprivation. The converse was observed in the mAkt-expressing cells. Rapamycin treatment completely suppressed the survival of IL-3-deprived mAkt-expressing cells, whereas cycloheximide had a minimal effect on mAkt-dependent survival. Neither the Pim-2 nor mAkt lines could survive IL-3 withdrawal in the presence of both drugs and died with kinetics identical to vector control.

The antiapoptotic effects of Pim-2 and Akt are additive

The antiapoptotic effects of Pim-2 and Akt are phenotypically similar but appear functionally distinct. To determine whether the combination of Pim-2 and Akt transgenes led to enhanced growth factor-independent survival Pim-2 and mAkt were stably coexpressed in FL5.12 cells. A clone expressing Pim-2 and Akt at levels similar to the lines expressing either gene alone was chosen for further study. In the Pim-2+mAkt coexpressors we observed a pronounced resistance to apoptosis following IL-3 withdrawal (Fig. 7A). For example, $\sim 85 \%$ of the Pim-2+mAkt coexpressors were viable after $4 \mathrm{~d}$ of IL-3 withdrawal (Fig. 7A) as compared with $40 \%$ viability evident in the cells that expressed either gene alone. Treatment of the IL-3-withdrawn Pim-2+mAkt-coex- pressing cells with cycloheximide reduced their survival to a level close to that observed in cells expressing mAkt alone. Treatment of the Pim-2+mAkt line with rapamycin in the absence of IL-3 decreased viability to a level similar to that of the line expressing Pim-2 alone. Simultaneous treatment of the Pim-2+mAkt cells with both cycloheximide and rapamycin fully repressed the protective influences of Pim-2 and Akt. Under these conditions, $<1 \%$ of the coexpressing cells were alive after $3 \mathrm{~d}$ of IL-3 withdrawal (Fig. 7A), kinetics identical to IL-3withdrawn vector control cells (Fig. 2C). In contrast, we found that IL-3-withdrawn Bcl- $\mathrm{x}_{\mathrm{L}}$-expressing cells were resistant to the effects of cycloheximide and rapamycin either alone or in combination (Fig. 7A).

\section{Endogenous levels of Pim-2 contribute to growth factor-induced apoptotic resistance}

Both Akt activation and Pim-2 expression are induced by IL-3. Their ability to stimulate distinct antiapoptotic pathways suggests that they may be redundant mediators of cell survival in response to growth factors. To address this issue, the ability of FL5.12 cells to accumulate in response to IL-3 was examined when Akt was suppressed by rapamycin treatment and endogenous Pim-2 was suppressed via RNA interference (Pim-2 RNAi) or by introduction of a dominant-negative transgene (Pim-2-KD). The Pim-2 RNAi construct suppressed endogenous Pim-2 expression relative to the empty vector control but had no effect on Pim-1 expression (Fig. $7 \mathrm{~B}$, right panels). Treatment of control cells with rapamycin led to only a small decrease in their IL-3-induced accumulation (Fig. 7B). After $4 \mathrm{~d}$ of treatment, the rapamycin-treated cells reached a density of about $10^{6} / \mathrm{mL}$ as compared with $1.5 \times 10^{6} / \mathrm{mL}$ in control. In the absence of rapamycin, both the Pim-2 RNAi and Pim-2-KD cells accumulated to a comparable density $\left(1.5 \times 10^{6} / \mathrm{mL}\right)$. However, when either Pim-2 RNAi or Pim-2-KD cells were treated with rapamycin, the cells not only failed to accumulate, but underwent progressive apoptosis despite the continued presence of IL-3. In contrast, IL-3induced cell accumulation could be rendered completely resistant to rapamycin by the ectopic expression of Pim-2.

Pim-2 activity results in phosphorylation of proapoptotic proteins

Multiple studies have described a primary role for the PI3K/Akt/TOR pathway in regulating cell size, metabolic activity, and survival. Recent work has identified 4E-BP1 as one of the essential effectors of this pathway. Although multiple phosphorylated forms of 4E-BP1 are evident in cycling cells, only one is phosphorylated at Ser 65, a feature absolutely required for formation of the active translational initiation complex. Phospho-Ser 654E-BP1 (p-S65-4E-BP1), as well as additional phosphorylated forms, was readily detected in FL5.12 cells in the presence of IL-3 but was undetectable after $6 \mathrm{~h}$ of IL-3 
A

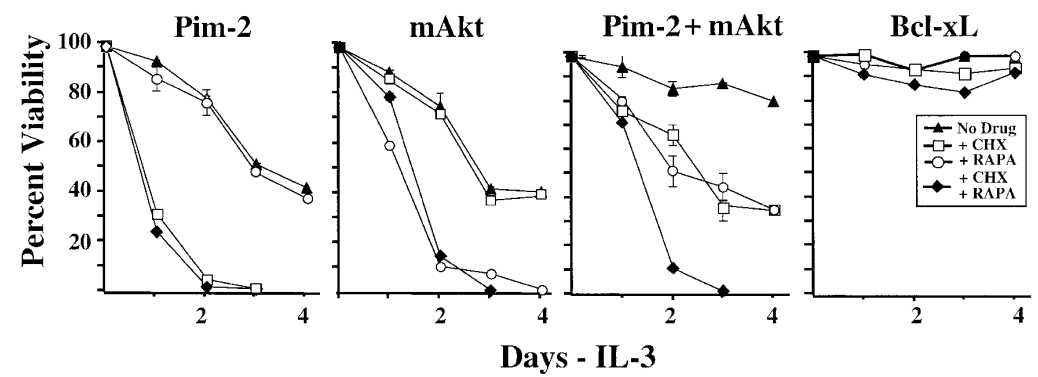

B
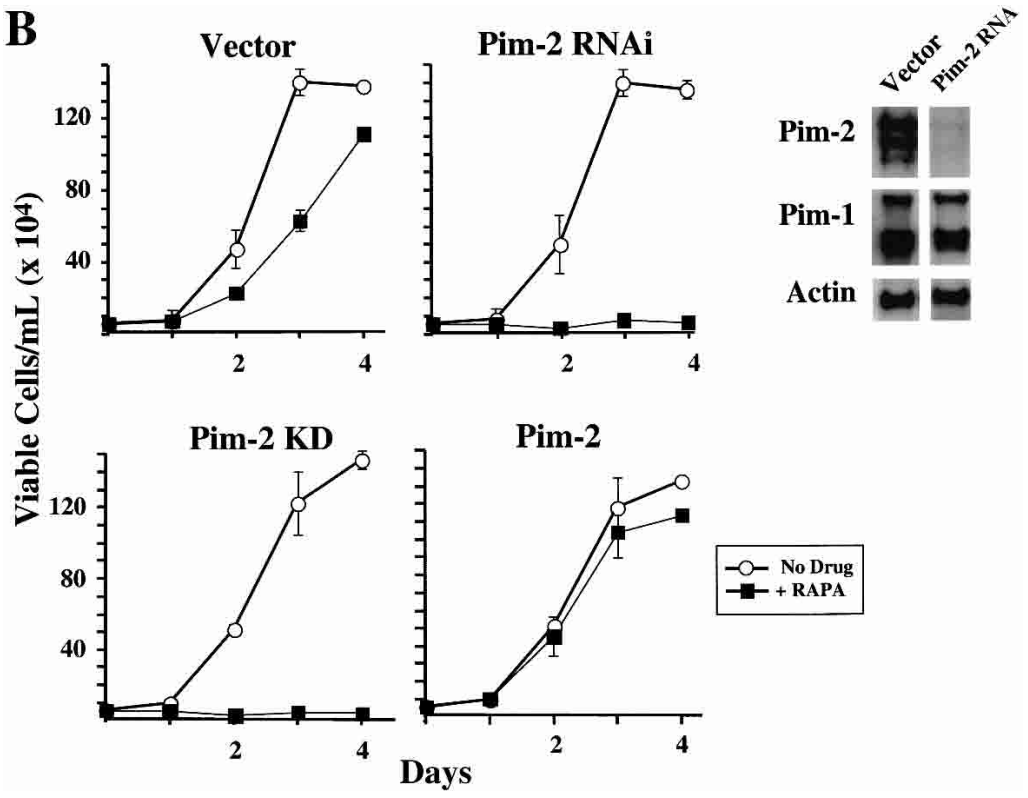

C

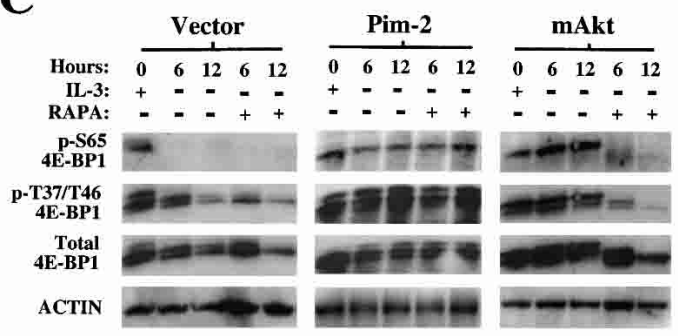

D

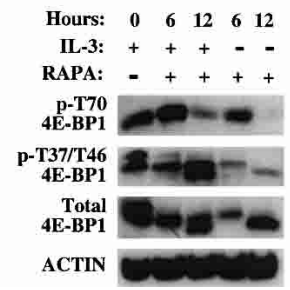

$\mathbf{E}$

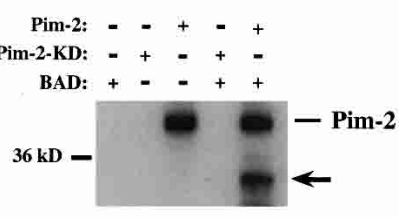

Figure 7. Pim-2 contributes to growth factor-induced apoptotic resistance independently of Akt. (A) The Pim-2, mAkt, and Bcl- $\mathrm{x}_{\mathrm{L}}$ lines, or FL5.12 cells coexpressing Pim-2 and mAkt transgenes, were withdrawn from IL-3 in the presence of no $\operatorname{drug}(\mathbf{\Delta}), 10 \mu \mathrm{g} / \mathrm{mL}$ cycloheximide (+CHX; $\square), 25$ $\mathrm{nM}$ rapamycin (+RAPA; $)$, or both cycloheximide and rapamycin $(+\mathrm{CHX}+\mathrm{RAPA}$; $)$ and viability assessed daily for the next $4 \mathrm{~d}$. Vector control cells died with rapid kinetics following IL-3 withdrawal independent of inhibitor addition (see Fig. 2C for representative data). Data in figure are the mean \pm S.D. of triplicate samples and are representative of three independent experiments. (B) FL5.12 cells expressing empty vector, Pim-2 RNAi, Pim-2-KD, or Pim-2 were plated at a density of $5 \times 10^{4} / \mathrm{mL}$ in IL-3 in the presence of no drug (O) or +RAPA ( $\square$ ) and the accumulation of viable cells assessed daily for the next $4 \mathrm{~d}$. Viable cells per milliliter $\times 10^{5}$ versus days posttreatment are shown. The data represent the mean \pm S.D. of triplicates and are representative of six independent experiments. Lysates from vector and Pim-2 RNAi cells were serially probed for endogenous Pim-2, Pim-1, and Actin by Western blot. $(C)$ Lysates were prepared from the vector control, Pim-2, and mAkt lines at 0, 6, and 12 $\mathrm{h}$ post-IL-3 withdrawal in the presence or absence of RAPA and 4E-BP1 phosphorylation examined by serial stripping and reprobing of Western blots with anti-phospho-Ser 65-4E-BP1 (pS65-4E-BP1), anti-phospho-Thr 37/Thr 46-4EBP1 (p-T37/T46-4E-BP1), anti-total 4E-BP1, and ACTIN. (D) Lysates were prepared from control cells grown in IL-3 in the presence of $25 \mathrm{nM}$ RAPA for 6 or $12 \mathrm{~h}$, and from cells withdrawn from IL-3 in the presence of RAPA over a similar time course. The Western blot was serially stripped and reprobed with anti-phospho-Thr 704E-BP1 (p-T70-4E-BP1), p-T37/T46-4E-BP1, antitotal 4E-BP1, and ACTIN. (E) Recombinant Pim-2 was purified from insect SF9 cells and used for in vitro kinase assays with recombinant BAD as substrate. To control for nonspecific kinases in the insect cell lysates, Pim-2-KD was prepared in an identical manner. As a negative control, a reaction containing substrate but no Pim-2 was performed. A representative autoradiograph is presented. The top band corresponds to autophosphorylated Pim-2 as indicated. The bottom band indicated by the arrow corresponds to the $30-\mathrm{kD}$ recombinant $\mathrm{BAD}$ protein. withdrawal (Fig. 7C, left panels). In contrast, p-S65-4EBP1 was maintained in both the Pim-2 (Fig. 7C, middle panels) and mAkt lines (Fig. 7C, right panels) following
IL-3 withdrawal. The ability of Pim-2 and Akt to maintain hyperphosphorylated 4E-BP1 in the absence of growth factor could be clearly distinguished following 
treatment of the cells with rapamycin. Rapamycin completely suppressed the ability of Akt transfected cells to maintain hyperphosphorylated 4E-BP1, whereas rapamycin had no effect on the levels of hyperphosphorylation 4E-BP1 observed in Pim-2-transfected cells.

The induction of Pim-2 may account for the ability of IL-3 to continue to stimulate 4E-BP1 phosphorylation (Fig. 7D) and cell growth (Fig. 7B) in the presence of rapamycin. As increased availability of eIF-4E has been linked to increased apoptotic resistance of cells, it is possible that Pim-2 may mediate all of its antiapoptotic effects by maintaining 4E-BP1 inactivity. However, other antiapoptotic kinases, such as Akt, can phosphorylate and regulate multiple apoptotic substrates. Another proapoptotic protein whose activity is inhibited by phosphorylation is BAD. To determine if Pim-2 is potentially capable of regulating BAD activity, we next determined whether purified Pim-2 could phosphorylate recombinant BAD in vitro. As shown in Figure 7E, purified Pim-2 showed robust autophosphorylation activity (top bands) absent in the lanes containing Pim-2-KD. Kinase active Pim-2, but not Pim-2-KD, also phosphorylated BAD protein (Fig. 7E, arrow).

\section{Discussion}

Growth factor-dependent signal transduction is critical in promoting cell survival during normal tissue homeostasis. One transcriptional target of a wide variety of hematopoietic growth factors is the serine/threonine kinase Pim-2. Unlike most other serine/threonine kinases, Pim-2 activity appears to be primarily regulated at the level of expression. Ectopically introduced Pim-2 is catalytically active in the absence of serum or growth factor stimulation. Pim-2 kinase activity results in resistance to a variety of apoptotic stimuli. The ability of Pim-2 to promote cell survival appears to be mechanistically distinct from that mediated by the antiapoptotic members of the Bcl-2 protein family and activated Akt. Like Akt, Pim-2 expression results in the cell-autonomous maintenance of cell size, metabolism, and survival in growth factor-deprived cells. Unlike Akt, Pim-2 promotion of cell survival is resistant to rapamycin. This feature correlated with the ability of Pim-2 to maintain phosphorylation of the proapoptotic translational inhibitor 4E-BP1 in a rapamycin-resistant manner. However, Pim-2 may not regulate apoptosis solely through phosphorylation of a single apoptotic regulator. The proapoptotic protein BAD, which can be inhibited by phosphorylation by multiple kinases, including Akt, is also phosphorylated, at least in vitro, by Pim-2. Thus, like Akt, Pim-2 may regulate the cellular resistance to apoptosis through the phosphorylation of more than one apoptotic regulatory protein. Together, these results suggest that Pim-2 and Akt are components of parallel and redundant antiapoptotic pathways that converge on an overlapping set of effector molecules to maintain cell survival and size control. It appears that both activation of Akt and induction of Pim-2 expression contribute to the apoptotic resistance induced by IL-3 signal transduction. Taken to- gether, these data suggest that growth factor-induced transcription of Pim-2 results in the activation of a novel kinase-dependent pathway that promotes cell-autonomous survival.

Although Pim-2 was discovered as an oncogene involved in lymphoid transformation (for review, see Allen and Berns 1996), its activities are distinct from those of other acutely regulated transcriptional targets of growth factor signal transduction. Most of the oncogenes implicated in malignant transformation of lymphocytes, such as c-Myc, induce cell growth or proliferation and are proapoptotic when expressed in isolation. In contrast, Pim-2 expression results in resistance to apoptosis without inducing cell proliferation. Pim-2-protected cells can survive for an extended period in the absence of growth factor and also continue to carry out a variety of anabolic cellular processes, including glycolysis, the maintenance of mitochondrial membrane potential and the prevention of cellular atrophy. Thus, these data suggest that Pim-2 participates in oncogenic transformation primarily by regulating cell survival rather than cell proliferation. This may explain the ability of Pim-2 to cooperate with c-Myc in malignant transformation of lymphocytes. Isolated expression of c-Myc leads to dysregulated cell growth and predisposes cells to apoptosis, a feature that can be suppressed by the addition of cytokines. One way that cytokines can suppress apoptosis is through the transcriptional induction of Pim-2. Consistent with this idea, Pim-2 and c-Myc transgenes can act cooperatively to promote the development of lymphomas that kill double transgenic animals shortly after birth (Allen et al. 1997).

Many of the features of Pim-2-expressing cells recapitulate the phenotypic impact of constitutive Akt activation. Nevertheless, ectopic Pim-2 expression has no measurable influence on Akt expression, its phosphorylation status, or its activity. Further, the ability of Pim-2 to promote cell survival in the absence of growth factor is independent of several Akt regulators, including PI3K, HSP-90, and TOR. Thus, it appears that Pim-2 and PI3K/ Akt/TOR function to promote cell-autonomous survival via distinct pathways, each of which maintains cellular trophism and mitochondrial potential in the absence of growth factors. Unlike the manipulation of the Bcl-2 proteins, Pim-2 does not promote cell survival in response to glucose withdrawal. In addition, cells in which apoptosis is suppressed through the activities of antiapoptotic Bcl-2 proteins display a pronounced delay in cell cycle entry following mitogenic stimulation (Mazel et al. 1996; O'Reilly et al. 1996; Fig. 4). In contrast, factordeprived activated Akt and Pim-2-expressing cells maintained a larger $\mathrm{G}_{0}$ cell size than Bcl- $\mathrm{x}_{\mathrm{L}}$-protected cells and rapidly entered the cell cycle following IL-3 addition. One mechanism activated Akt and Pim-2 share that may contribute to the maintenance of both cell size and survival is the phosphorylation of the proapoptotic translational repressor 4E-BP1. Phosphorylation of 4E-BP1 on Ser 65 (S65) has been shown to inhibit 4E-BP1 binding to eIF4E, thus stimulating cap-dependent translation (for review, see Clemens et al. 2000). S65 phosphorylation of 
4E-BP1 inhibits its proapoptotic activity (S. Li et al. 2002). However, the Pim-2 and Akt-dependent maintenance of 4E-BP1 phosphorylation is mechanistically distinct, as Akt-induced phosphorylation is rapamycin-sensitive, whereas Pim-2-induced 4E-BP1 phosphorylation is rapamycin-insensitive. Taken together, these data suggest that Pim-2 functions in a novel pathway to promote cell survival independent of the Bcl-2 family and PI3K/ Akt/TOR.

Pim-2 is a member of a small family of oncogenic serine/threonine kinases. Pim-1, Pim-2, and Pim-3 were each identified as sites of viral insertion in retrovirallyinduced murine leukemia (Selten et al. 1985; Breuer et al. 1989; Feldman et al. 1998; Konietzko et al. 1999; Giza et al. 2002). Like Pim-2, Pim-1 is transcriptionally induced in lymphocytes in response to multiple mitogenic signals and Pim-1 can synergize with c-Myc, N-Myc, or L-Myc to promote malignant transformation (Moroy et al. 1991; Verbeek et al. 1991; Allen et al. 1997). These observations led to the hypothesis that Pim-1 and Pim-2 may be functionally redundant (van der Lugt et al. 1995; Mikkers et al. 2002). Recent work has established a role for Pim-1 in cell cycle progression, a property it shares with several other genes known to collaborate with Myc in cell transformation. In response to mitogenic stimulation, Pim-1 translocates to the nucleus where it forms a complex with the transcriptional coactivator, p100, leading to stimulation of the transcriptional activity of $\mathrm{c}-\mathrm{Myb}$, a regulator of hematopoietic cell proliferation (Leverson et al. 1998). Activated Pim-1 further promotes cell proliferation by phosphorylating and activating Cdc25A, a key regulator of cell cycle progression (Mochizuki et al. 1999). In contrast, ectopic Pim-2 expression has no effect on cell cycle distribution or proliferative rate in the presence or absence of IL-3. These differences may reflect the fact that despite the similarities in their kinase domains, Pim-1 and Pim-2 do not share significant homology outside of the kinase domain. This suggests that Pim-1 and Pim-2 may not target identical substrates or pathways. Alternatively, unlike Pim-2, Pim-1 kinase activity may not be constitutive and may require additional modification to participate in the regulation of apoptosis. We and other groups have investigated Pim-1 as a potential apoptotic regulator. Pim-1 expression has, at best, a modest effect on growth factorindependent survival, in one study even accelerating apoptosis in response to growth factor withdrawal (Mochizuki et al. 1999) and Pim-1 has no clear role in the regulation of cell death in response to other apoptotic initiators (Lilly et al. 1999; Pircher et al. 2000; Wang et al. 2001; C.J. Fox, P.S. Hammerman, and C.B. Thompson, unpubl.). Finally, selective inhibition of endogenous levels of Pim-2 by RNAi renders cells sensitive to apoptosis induced by inhibition of the PI3K/Akt/TOR pathway despite continued presence of Pim-1.

In conclusion, these results suggest that Pim-2 has a novel role in linking growth factor-dependent transcription to a kinase-regulated pathway that promotes cell autonomous survival. The existence of an antiapoptotic pathway with phenotypic effects on cell size and me- tabolism similar to those observed for the PI3K/Akt/ TOR pathway was unexpected. However, the data suggest that the growth factor-dependent induction of endogenous Pim-2 accounted for the poor ability of PI3K inhibitors or rapamycin to suppress growth factor-induced cell growth and survival. The ability of Pim-2 to maintain rapamycin-resistant 4E-BP1 hyperphosphorylation is unprecedented. 4E-BP1 phosphorylation is believed to be TOR-dependent and in all previous studies is susceptible to rapamycin. Recently, the existence of a rapamycin-insensitive TOR complex has been demonstrated in yeast (Loewith et al. 2002) and it is possible that Pim-2 regulates a similar complex in mammals. Alternatively, Pim-2 may maintain 4E-BP1 hyperphosphorylation indirectly by affecting a kinase with a substrate specificity that overlaps that of TOR. Given the critical nature of cell growth and survival control, it is perhaps not surprising that independent pathways exist to regulate key steps in the control of cell growth and survival.

\section{Materials and methods}

Plasmids

The full-length, murine Pim-2-L1 transgene was generated by PCR as follows: $94^{\circ} \mathrm{C}, 30 \mathrm{sec} ; 60^{\circ} \mathrm{C}, 35 \mathrm{sec}$; and $72^{\circ} \mathrm{C}, 40 \mathrm{sec}$ for 30 cycles using forward primer $5^{\prime}$-GGGGCTGGCGCGCGC GACG-3', reverse primer 5'-CTAGGGAAGCAGGGACCAG GGCAA-3' and murine pim-2 cDNA (Breuer et al. 1989) as template. Pim-2-L1M was generated by PCR-directed mutagenesis (forward primer 5'-GGGGATGGCGCGCGCGACG-3' and the above reverse primer). PCR products were cloned into the pCR2.1-TOPO and the pEF6-TOPO mammalian expression vectors as directed by the manufacturer (Invitrogen). The pCR2.1 inserts were then shuttled into the pSFFV and pIRESPURO (Clontech) mammalian expression vector using standard methods. pEF6 contains the human elongation factor one $\alpha$ promoter and pSFFV the promoter of the spleen focus-forming virus. To generate Pim-2-KD, the lysine residue at position 121 was mutated to methionine via oligonucleotide-directed mutagenesis (forward mutagenic primer, 5'-GGTGGCCATCATGG TAATCTCCCGG-3'; reverse primer, 5'-CCGGGAGATTAC CATGATGGCCACC-3') as directed by the manufacturer (QuikChange, Stratagene). Kinase-active Pim-2 and Pim-2-KD, both with C-terminal c-Myc epitope tags, were generated in a similar manner except the reverse primer lacked a stop codon (5'-GGGAAGCAGGGACCAGGGCAAGGGG-3') and were shuttled from pEF6-TOPO to the pEF6-Myc vector (Invitrogen). pEF6 and pIRES-PURO vectors containing human Bcl- $\mathrm{x}_{\mathrm{L}}$ (for-

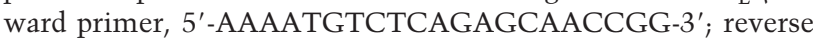
primer, 5'-AGTGGACGGTCAGTGTCTGGT-3') and a constitutively-activated Akt containing a c-SRC N-terminal myristoylation site (5'-GCTTATGGGGAGCAGCAAGAGCAA-3'; reverse primer, 5'-GCCTCAGGCTGTGCCACTGGC-3') were cloned in a similar manner, using cDNA-containing plasmids as templates (Rathmell et al. 2000; Plas et al. 2001). A pKD construct used to express short hairpins for RNAi was derived from pBabe-PURO by deleting a portion of the $3^{\prime}$ LTR. The human U6 RNA polymerase III promoter (bases -265 to -1 ) was PCRamplified from HeLa cell genomic DNA and cloned into pEF6TOPO (pEF6-hU6). To generate short hairpin RNAs (shRNA) for RNAi, a PCR-based strategy was employed using pEF6-hU6 as a template and primers containing a Pim-2 DNA hairpin se- 
Fox et al.

quence (sense, 5'-GGGATAGATGGACATCTGTTGAA- ${ }^{\prime}$ ). The resultant PCR product was cloned into pEF6-TOPO, the promoter and hairpin region excised and shuttled to the pKD vector $(\mathrm{pkD}$-im2b). A plasmid containing full length murine $\beta$-actin cDNA has been described elsewhere (C. Li et al. 2002). All oligonucleotide primers were purchased from GIBCO-BRL. Twenty micrograms of each plasmid was then used to transform cells by electroporation ( $975 \mu \mathrm{F}$ capacitance, $250 \mathrm{mV}$ ).

\section{Cell lines and cell culture}

All cell culture experiments were performed in triplicate. Following transformation, cells were selected in $1 \mathrm{mg} / \mathrm{mL}$ Geneticin (GIBCO) for the pSFFV vector, $20 \mu \mathrm{g} / \mathrm{mL}$ of Blasticidin Shydrochloride (Invitrogen) for the pEF6 vectors, or $1 \mu \mathrm{g} / \mathrm{mL}$ puromycin for pIRES-PURO and pKD-IM2b. Clones were generated from stable bulk cultures by limiting dilution. As controls, parallel lines were generated using the appropriate empty vector. FL5.12 cells were maintained in RPMI 1640 (GIBCO) supplemented with $10 \%$ fetal calf serum (FCS; Mediatech), Penicillin/Streptomycin (P/S; GIBCO) and $400 \mathrm{pg} / \mathrm{mL}$ recombinant murine interleukin-3 (Pharmingen). 2B4.11, WEHI3B, UC10-4F10, 145-2C11, Jurkat, and HeLa cells were grown in RPMI $+10 \%$ FCS $+\mathrm{P} / \mathrm{S}$. To withdraw FL5.12 cells from growth factor, the cells were washed four times in RPMI $+10 \%$ FCS and resuspended in fresh medium without the addition of IL-3. Serum withdrawal was accomplished by washing cells four times in RPMI and then resuspending in $\mathrm{RPMI}+\mathrm{P} / \mathrm{S}$. Additional reagents for cell culture were purchased as follows: CCCP, TMRE, rapamycin, and wortmannin were purchased from Sigma-Aldrich; staurosporine, thapsigargin, LY294002, cycloheximide, geldanamycin, 1L-6-hydroxymethylchiro-inositol 2-(R)-2-O-methyl-3-O-octadecylcarbonate, and radicicol were purchased from Calbiochem. Stock concentrations of each drug were made in the appropriate solvent as recommended by the manufacturer. Inhibitors were added to cell culture at the concentrations indicated on days 0 and 2 post-IL-3 withdrawal.

\section{RNA isolation, microarray analysis, and Northern blotting}

Total RNA was prepared from FL5.12 cells via the cesium chloride method. cRNA preparation, sequential hybridization to Affymetrix Test II, murine $11 \mathrm{~K}$ sub A and sub B oligonucleotide microarrays and data analysis have been described in detail elsewhere (C. Li et al. 2002). All RNA isolation, microarray, and Northern analyses were performed in triplicate. Total RNA 15 $\mu \mathrm{g})$ was resolved on $2 \%$ agarose gels containing $2.5 \%$ formaldehyde and Northern blotting performed as described (Rathmell et al. 2000). Northern blots were stripped by washing three times in boiling $1 \%$ SDS. The full-length murine pim-2 and $\beta$-actin cDNA probes were radiolabeled via standard methods.

Western blots, antibodies, in vitro translation, recombinant Pim-2 isolation, and kinase assay

Whole-cell extracts were prepared in phosphate buffered saline (PBS) containing 1\% Triton-X (Sigma-Aldrich) supplemented with protease inhibitors (Roche) and phosphatase inhibitor cocktails I and II (Sigma-Aldrich), as directed by the manufacturers. Protein concentrations were determined by the Dc protein assay (Bio-Rad). For Western blots, $20-150 \mu \mathrm{g}$ of total protein was resolved on $4 \%-12 \%$ or $10 \%$ NuPage bis-tris polyacrylamide gels and transferred to nitrocellulose as directed (Invitrogen), then blocked in PBS containing 10\% milk $+0.2 \%$ Tween-20 and incubated with the primary antibody in 5\% milk overnight at $4^{\circ} \mathrm{C}$. For the $4 \mathrm{E}-\mathrm{BP} 1$ Western blots, $100 \mu \mathrm{g}$ of total lysate was resolved on $18 \%$ Tris-Acetate gels and blotted according to manufacturer's instructions (Invitrogen). Western blots were stripped by incubating for $30 \mathrm{~min}$ at $65^{\circ} \mathrm{C}$ in $2 \%$ SDS + $100 \mathrm{mM} \beta$-mercaptoethanol, followed by four washes in PBS. Mouse anti-Pim-2 1D12, rabbit anti-c-Myc A-14, and goat anti-actin C-11 were purchased from Santa Cruz. Rabbit antitotal Akt, anti-phospho-Ser 473-AKT, anti-total 4E-BP1, antiphospho-Ser 65-4E-BP1, anti-phospho-Thr 70-4E-BP1, antiphospho-Thr 37/Thr 46-4E-BP1, and anti-phospho-GSK3 $\beta$ were purchased from Cell Signaling. Rabbit-anti-phospho-Thr 308 was purchased from Affinity Bioreagents. Rabbit anti-human Bcl- $\mathrm{x}_{\mathrm{L}} 13.6$ was generated using standard methods. The appropriate horseradish-peroxidase-conjugated secondary antibodies (Santa Cruz) and ECL-Plus or ECL-Advance chemiluminescent reagents (Amersham Biosciences) were used to visualize the target proteins. For the Pim-2 immunoprecipitation experiments, $2 \mathrm{mg}$ of total cellular lysate in a total volume of $1 \mathrm{~mL}$ of lysis buffer was incubated with $1 \mu \mathrm{g}$ of 1D12 antibody and mixed at $4^{\circ} \mathrm{C}$ for $1 \mathrm{~h}$. Twenty microliters of protein G-agarose beads (Invitrogen) were then added and mixed for $2 \mathrm{~h}$ at $4^{\circ} \mathrm{C}$. The beads were collected by centrifugation, unbound protein removed by multiple washes in PBS and then resuspended in kinase buffer (25 mM HEPES at $\mathrm{pH} 7.5,10 \mathrm{mM} \mathrm{MgCl} 2,0.5 \mathrm{mM}$ DTT). Pim-2 was also immunoprecipitated from in vitro-translated reactions using pEF6-Pim-2, pEF6-Pim-2-L1, pEF6-Pim-2-KD, or pEF6 empty vector as templates and the TNT-T7 Quick Coupled In Vitro Translation kit as directed by the manufacturer (Promega). Half of each reaction was used in a Pim-2 Western blot. Kinase assays were performed with the remainder as follows. Briefly, 25 $\mu \mathrm{g}$ of histone $\mathrm{Hl}$ or $1 \mu \mathrm{g}$ of purified BAD protein (both from Upstate) was used as substrate, $10 \mathrm{mM}$ of cold ATP and 10 $\mu$ Curies of $\gamma_{-}{ }^{32} \mathrm{P}$-ATP were then added and incubated for 30 min. Labeled protein was then resolved on a $16 \%$ Tris-glycine polyacrylamide gel (Invitrogen), the gel dried and then exposed to film. Recombinant Pim-2 and Pim-2-KD were generated as follows: Pim-2 and Pim-2-KD containing $8 \times$ His epitope tags were cloned into the pVL1393 vector and used to generate recombinant Baculovirus by transfection of insect SF9 cells using the Baculogold Baculouvirus production kit (BD Biosciences). Following two steps of amplification, SF9 cells were infected at a multiplicity of infection of 10 for $3 \mathrm{~d}$ and then lysed in a buffer containing $300 \mathrm{mM} \mathrm{NaCl}, 50 \mathrm{mM} \mathrm{NaH}_{2} \mathrm{PO}_{4}, 10 \mathrm{mM}$ imidazole, and $1 \%$ NP40. Purification of the tagged Pim proteins was performed using Ni-NTA beads according to the QIAexpressionist (Qiagen) protocol. Recovered protein was then dialyzed overnight in a buffer containing $150 \mathrm{mM} \mathrm{NaCl}, 1 \mathrm{mM}$ DTT, $1 \mathrm{mM}$ PMSF and $20 \%$ glycerol and protein concentration approximated by comparison with BSA standards using a Coomassie stained SDS-PAGE gel. Approximately $10 \mathrm{ng}$ of recombinant Pim was used in subsequent kinase assays as described above.

Glucose withdrawal, glycolysis, and supernatant lactate assay

For the glucose withdrawal experiments, FL5.12 cells were washed four times in culture medium composed of glucose-free RPMI and $10 \%$ dialyzed FCS (both from GIBCO) supplemented with IL-3 and $20 \mu \mathrm{M}$ glucose (1:500 dilution of standard RPMI) and resuspended in fresh medium for the duration of the experiment. Glycolysis was measured by monitoring the conversion of $5-{ }^{3} \mathrm{H}$-glucose to $3-\mathrm{H}_{2} \mathrm{O}$ and is described in detail elsewhere (Plas et al. 2001). Briefly, 1 million live cells were washed once in PBS before resuspension in $1 \mathrm{~mL}$ of Krebs buffer and incubated for $30 \mathrm{~min}$ at $37^{\circ} \mathrm{C}$. Cells were then resuspended in $0.5 \mathrm{~mL}$ of Krebs buffer containing glucose (10 $\mathrm{mM}$, if not specified) and 
spiked with $10 \mu \mathrm{Ci}$ of $5{ }^{3} \mathrm{H}$-glucose. Following incubation for 1 $\mathrm{h}$ at $37^{\circ} \mathrm{C}$, triplicate $50-\mu \mathrm{l}$ aliquots were transferred to tubes containing $50 \mu \mathrm{l}$ of $0.2 \mathrm{~N} \mathrm{HCl}$, and placed in a scintillation vial containing $0.5 \mathrm{~mL}$ of water. The vials were sealed, and diffusion was allowed to occur for $48 \mathrm{~h}$. The amounts of diffused and undiffused ${ }^{3} \mathrm{H}$ were determined by scintillation counting. Appropriate ${ }^{3} \mathrm{H}$-glucose-only and ${ }^{3} \mathrm{H}_{2} \mathrm{O}$-only controls were included, enabling the calculation of ${ }^{3} \mathrm{H}_{2} \mathrm{O}$ in each sample and thus the rate of glycolysis. The concentration of lactate in cell culture supernatants was assessed using an enzymatic diagnostic kit according to manufacturer's instructions (Sigma-Aldrich).

\section{Flow cytometry}

Cell viability and mean forward scatter were assessed by exclusion of $1 \mu \mathrm{g} / \mathrm{mL}$ propidium iodide (PI; Sigma-Aldrich), using a FACsCalibur flow cytometer (BD Biosciences). For cell cycle analysis, cells were fixed for $30 \mathrm{~min}$ in $70 \%$ ethanol at $4^{\circ} \mathrm{C}$ and then resuspended in PBS containing PI and $10 \mu \mathrm{g} / \mathrm{mL}$ RNase A (Promega). To assess BrdU uptake, live cells were enriched by Ficoll centrifugation as directed by the manufacturer (Amersham Biotech), washed twice in PBS, incubated with $10 \mu \mathrm{M}$ BrdU in PBS (Sigma-Aldrich) for $60 \mathrm{~min}$ at $37^{\circ} \mathrm{C}$ and then fixed for $10 \mathrm{~min}$ in $70 \%$ ethanol. Cell preparation using anti-BrdU and FITC-anti-Mouse IgG1 A85-1 antibodies was then performed as described by the manufacturer (PharMingen). To assess mitochondrial potential, viable cells were enriched by Ficoll centrifugation, washed and incubated for $30 \mathrm{~min}$ in $20 \mathrm{nM}$ TMRE at $37^{\circ} \mathrm{C}$. To determine background staining, parallel samples were also incubated in $50 \mu \mathrm{M}$ CCCP to collapse the mitochondrial potential. Cell accumulation was taken as the product of the number of cells per milliliter (quantified on a Coulter Z2 particle size analyzer) by cell viability.

\section{Acknowledgments}

We thank A. Berns for providing the pim-2 plasmid, and S. Reiner, T. Lindsten, J. Rathmell, A. Edinger, and S. Kerns for helpful comments on the manuscript. Portions of this work were supported by grants from the National Cancer Institute. C.J.F. is a recipient of a chapter grant Fellowship from the Arthritis Foundation.

The publication costs of this article were defrayed in part by payment of page charges. This article must therefore be hereby marked "advertisement" in accordance with 18 USC section 1734 solely to indicate this fact.

\section{References}

Algate, P.A., Steelman, L.S., Mayo, M.W., Miyajima, A., and McCubrey, J.A. 1994. Regulation of the interleukin-3 (IL-3) receptor by IL-3 in the fetal liver-derived FL5.12 cell line. Blood 83: 2459-2468.

Allen, J.D. and A. Berns. 1996. Complementation tagging of cooperating oncogenes in knockout mice. Semin Cancer Biol 7: 299-306.

Allen, J.D., Verhoeven, E., Domen, J., van der Valk, M., and Berns, A. 1997. Pim-2 transgene induces lymphoid tumors, exhibiting potent synergy with c-myc. Oncogene 15: 11331141.

Amson, R., Sigaux, F., Przedborski, S., Flandrin, G., Givol, D., and Telerman, A. 1989. The human protooncogene product p33pim is expressed during fetal hematopoiesis and in diverse leukemias. Proc. Nat1. Acad. Sci. 86: 8857-8861.

Arden, K.C. and Biggs III, W.H. 2002. Regulation of the FoxO family of transcription factors by phosphatidylinositol-3 kinase-activated signaling. Arch. Biochem. Biophys. 403: 292298.

Basso, A.D., Solit, D.B., Chiosis, G., Giri, B., Tsichlis, P., and Rosen, N. 2002. Akt forms an intracellular complex with Hsp90 and Cdc37 and is destabilized by inhibitors of Hsp90 function. J. Biol. Chem. 42: 39858-39866

Breuer, M.L., Cuypers, H.T., and Berns, A. 1989. Evidence for the involvement of pim-2, a new common proviral insertion site, in progression of lymphomas. EMBO J. 8: 743-781.

Claudio, J.O., Masih-Khan, E., Tang, H., Goncalves, J., Voralia, M., Li, Z.H., Nadeem, V., Cukerman, E., Francisco-Pabalan, O., Liew, C.C., et al. 2002. A molecular compendium of genes expressed in multiple myeloma. Blood 100:21752186.

Clemens, M.J., Bushell, M., Jeffrey, I. W., Pain, V. M., and Morley, S.J. 2000. Translation initiation factor modifications and the regulation of protein synthesis in apoptotic cells. Cell Death Differ. 7: 603-615.

Cory, S. and Adams, J.M. 2002. The bcl2 family: Regulators of the cellular life-or-death switch. Nat. Rev. Cancer 2: 647656.

Covey, D.F., Han, M., Kumar, A.S., de La Cruz, M.A., Meadows, E.S., Hu, Y., Tonnies, A., Nathan, D., Coleman, M., Benz, A., et al. 2000. Neurosteroid analogues. 8. Structure-activity studies of $\mathrm{N}$-acylated 17a-aza-D-homosteroid analogues of the anesthetic steroids $(3 \alpha, 5 \alpha)$ - and $(3 \alpha, 5 \beta)-3$-hydroxypregnan-20-one. J. Med. Chem. 43: 3201-3204.

D'Cruz, C.M., Moody, S.E., Master, S.R., Hartman, J.L., Keiper, E.A., Imielinski, M.B., Cox, J.D., Wang, J.Y., Ha, S.I., Keister, B.A., et al. 2002. Persistent parity-induced changes in growth factors, TGF- $\beta 3$, and differentiation in the rodent mammary gland. Mol. Endocrinol. 16: 2034-2051.

Dhanasekaran, S.M., Barrette, T.R., Ghosh, D., Shah, R., Varambally, S., Kurachi, K., Pienta, K.J., Rubin, M.A., and Chinnaiyan, A.M. 2001. Delineation of prognostic biomarkers in prostate cancer. Nature 412: 822-826.

Edinger, A.L. and Thompson, C.B. 2002. Akt maintains cell size and survival by increasing mTOR-dependent nutrient uptake. Mol. Biol. Cell 13: 2276-2288.

Feldman, J.D., Vician, L., Crispino, M., Tocco, G., Marcheselli, V.L., Bazan, N.G., Baudry, M., and Herschman, H.R. 1998 KID-1, a protein kinase induced by depolarization in brain. J. Biol. Chem. 273: 16535-16543.

Giza, C.C., Prins, M.L., Hovda, D.A., Herschman, H.R., and Feldman, J.D. 2002. Genes preferentially induced by depolarization after concussive brain injury: Effects of age and injury severity. J. Neurotrauma 19: 387-402.

Hoffman, B., Amanullah, A., Shafarenko, M., and Liebermann, D.A. 2002. The proto-oncogene c-myc in hematopoietic development and leukemogenesis. Oncogene 21: 3414-3421.

Huse, M. and Kuriyan, J. 2002. The conformational plasticity of protein kinases. Cell 109: 275-282.

Konietzko, U., Kauselmann, G., Scafidi, J., Staubli, U., Mikkers, H., Berns, A., Schweizer, M., Waltereit, R., and Kuhl, D. 1999. Pim kinase expression is induced by LTP stimulation and required for the consolidation of enduring LTP. EMBO $T$. 18: 3359-3369.

Leverson, J.D., Koskinen, P.J., Orrico, F.C., Rainio, E.M., Jalkanen, K.J., Dash, A.B., Eisenman, R.N., and Ness, S.A. 1998. Pim-1 kinase and p100 cooperate to enhance c-Myb activity. Mol. Cell 2: 417-425.

Li, C., Fox, C.J., Master, S.R., Bindokas, V.P., Chodosh, L.A., and Thompson, C.B. 2002. Bcl- $\mathrm{x}_{\mathrm{L}}$ affects $\mathrm{Ca}^{2+}$ homeostasis by altering expression of inositol 1,4,5-trisphosphate receptors. Proc. Natl. Acad. Sci. 99: 9830-9835. 
Li, J., Peet, G.W., Balzarano, D., Li, X., Massa, P., Barton, R.W., and Marcu, K.B. 2001. Novel NEMO/IkappaB kinase and NF-kappa B target genes at the pre-B to immature B cell transition. J. Biol. Chem. 276: 18579-18590.

Li, S., Sonenberg, N., Gingras, A.C., Peterson, M., Avdulov, S., Polunovsky, V.A., and Bitterman, P.B. 2002. Translational control of cell fate: Availability of phosphorylation sites on translational repressor 4E-BP1 governs its proapoptotic potency. Mol. Cell. Biol. 22: 2853-2861.

Lilly, M., Sandholm, J., Cooper, J.J., Koskinen, P.J., and Kraft, A. 1999. The Pim-1 serine kinase prolongs survival and inhibits apoptosis-related mitochondrial dysfunction in part through a bcl-2-dependent pathway. Oncogene 18: 4022-4031.

Loewith, R., Jacinto, E., Wullschleger, S., Lorberg, A., Crespo, J.L., Bonenfant, D., Oppliger, W., Jenoe, P., and Hall, M.N. 2002. Two TOR complexes, only one of which is rapamycin sensitive, have distinct roles in cell growth control. Mol. Cell 10: 457-468.

Mazel, S., Burtrum, D., and Petrie, H.T. 1996. Regulation of cell division cycle progression by bcl-2 expression: A potential mechanism for inhibition of programmed cell death. J. Exp. Med. 183: 2219-2226.

Mikkers, H., Allen, J., Knipscheer, P., Romeyn, L., Hart, A., Vink, E., and Berns, A. 2002. High-throughput retroviral tagging to identify components of specific signaling pathways in cancer. Nat. Genet. 32: 153-159.

Mikovits, J., Ruscetti, F., Zhu, W., Bagni, R., Dorjsuren, D., and Shoemaker, R. 2001. Potential cellular signatures of viral infections in human hematopoietic cells. Dis Markers 17: 173-178.

Mochizuki, T., Kitanaka, C., Noguchi, K., Muramatsu, T., Asai, A., and Kuchino, Y. 1999. Physical and functional interactions between Pim-1 kinase and Cdc25A phosphatase. Implications for the Pim-1-mediated activation of the c-Myc signaling pathway. J. Biol. Chem. 274: 18659-18666.

Moroy, T., Verbeek, S., Ma, A., Achacoso, P., Berns, A., and Alt, F. 1991. E mu N- and E mu L-myc cooperate with E mu pim-1 to generate lymphoid tumors at high frequency in double-transgenic mice. Oncogene 6: 1941-1948.

Muschen, M., Lee, S., Zhou, G., Feldhahn, N., Barath, V.S., Chen, J., Moers, C., Kronke, M., Rowley, J.D., and Wang, S.M. 2002. Molecular portraits of B cell lineage commitment. Proc. Natl. Acad. Sci. 99: 10014-1009.

Neill, G.W. and Kelsell, D.P. 2001. Spotting prostate cancer. Trends Mol. Med. 7: 432.

Nicholson, K.M. and Anderson, N.G. 2002. The protein kinase B/Akt signalling pathway in human malignancy. Cell Signal 14: 381-395.

Omura, S., Sasaki, Y., Iwai, Y., and Takeshima, H. 1995. Staurosporine, a potentially important gift from a microorganism. J. Antibiot. (Tokyo) 48: 535-548.

O'Reilly, L.A., Huang, D.C., and Strasser, A. 1996. The cell death inhibitor Bcl-2 and its homologues influence control of cell cycle entry. EMBO J. 15: 6979-6990.

Pelengaris, S., Khan, M., and Evan, G. 2002. c-myc: More than just a matter of life and death. Nat. Rev. Cancer 2: 764-776.

Pircher, T.J., Zhao, S., Geiger, J.N., Joneja, B., and Wojchowski, D.M. 2000. Pim-1 kinase protects hematopoietic FDC cells from genotoxin-induced death. Oncogene 19: 3684-3692.

Plas, D.R., Talapatra, S., Edinger, A.L., Rathmell, J.C., and Thompson, C.B. 2001. Akt and Bcl- $\mathrm{x}_{\mathrm{L}}$ promote growth factor-independent survival through distinct effects on mitochondrial physiology. J. Biol. Chem. 276: 12041-12048.

Rathmell, J.C., Vander Heiden, M.G., Harris, M.H., Frauwirth, K.A., and Thompson, C.B. 2000. In the absence of extrinsic signals, nutrient utilization by lymphocytes is insufficient to maintain either cell size or viability. Mol. Cell 6: 683-692.

Schulte, T.W., Akinaga, S., Murakata, T., Agatsuma, T., Sugimoto, S., Nakano, H., Lee, Y.S., Simen, B.B., Argon, Y., Felts, S., et al. 1999. Interaction of radicicol with members of the heat shock protein 90 family of molecular chaperones. Mol. Endocrinol. 13: 1435-1448.

Selten, G., Cuypers, H.T., and Berns, A. 1985. Proviral activation of the putative oncogene Pim-1 in MuLV induced T-cell lymphomas. EMBO J. 4: 1793-1798.

Temple, R., Allen, E., Fordham, J., Phipps, S., Schneider, H.C., Lindauer, K., Hayes, I., Lockey, J., Pollock, K., and Jupp, R. 2001. Microarray analysis of eosinophils reveals a number of candidate survival and apoptosis genes. Am. J. Respir. Cell. Mol. Biol. 25: 425-433.

Treiman, M., Caspersen, C., and Christensen, S.B. 1998. A tool coming of age: Thapsigargin as an inhibitor of sarco-endoplasmic reticulum $\mathrm{Ca}^{2+}$-ATPases. Trends Pharmacol. Sci. 19: 131-135.

Tulchinsky, E. 2000. Fos family members: Regulation, structure and role in oncogenic transformation. Histol. Histopathol. 15: 921-928.

van der Lugt, N.M., Domen, J., Verhoeven, E., Linders, K., van der Gulden, H., Allen, J., and Berns, A. 1995. Proviral tagging in E mu-myc transgenic mice lacking the Pim-1 proto-oncogene leads to compensatory activation of Pim-2. EMBO $J$. 14: $2536-2544$.

Verbeek, S., van Lohuizen, M., van der Valk, M., Domen, J., Kraal, G., and Berns, A. 1991. Mice bearing the E $\mu$-myc and E $\mu$-pim-1 transgenes develop pre-B-cell leukemia prenatally. Mol. Cell. Biol. 11: 1176-1179.

Vlahos, C.J., Matter, W.F., Hui, K.Y., and Brown, R.F. 1994. A specific inhibitor of phosphatidylinositol 3-kinase, 2-(4-morpholinyl)-8-phenyl-4H-1-benzopyran-4-one (LY294002). I. Biol. Chem. 269: 5241-5248.

Wang, Z., Bhattacharya, N., Meyer, M.K., Seimiya, H., Tsuruo, T., Tonani, J.A., and Magnuson, N.S. 2001. Pim-1 negatively regulates the activity of PTP-U2S phosphatase and influences terminal differentiation and apoptosis of monoblastoid leukemia cells. Arch. Biochem. Biophys. 390: 9-18.

Xu, L.G., Wu, M., Hu, J., Zhai, Z., and Shu, H.B. 2002. Identification of downstream genes up-regulated by the tumor necrosis factor family member TALL-1. J. Leukoc. Biol. 72: 410-416.

Yoshida, S., Kaneita, Y., Aoki, Y., Seto, M., Mori, S., and Moriyama, M. 1999. Identification of heterologous translocation partner genes fused to the BCL6 gene in diffuse large B-cell lymphomas: 5'-RACE and LA-PCR analyses of biopsy samples. Oncogene 18: 7994-7999. 


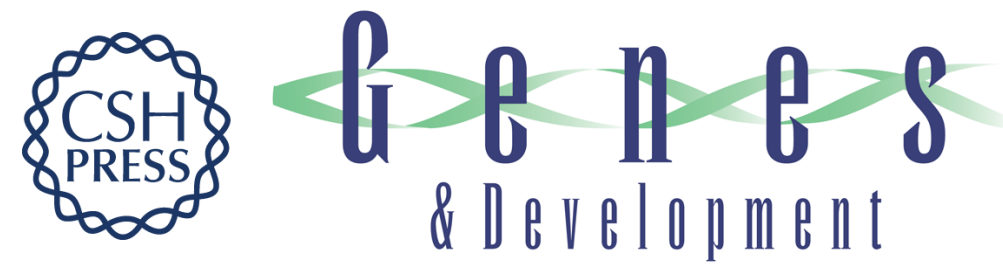

\section{The serine/threonine kinase Pim-2 is a transcriptionally regulated apoptotic inhibitor}

Casey J. Fox, Peter S. Hammerman, Ryan M. Cinalli, et al.

Genes Dev. 2003, 17:

Access the most recent version at doi:10.1101/gad.1105003

References This article cites 49 articles, 15 of which can be accessed free at: http://genesdev.cshlp.org/content/17/15/1841.full.html\#ref-list-1

License

Email Alerting

Receive free email alerts when new articles cite this article - sign up in the box at the top Service right corner of the article or click here.

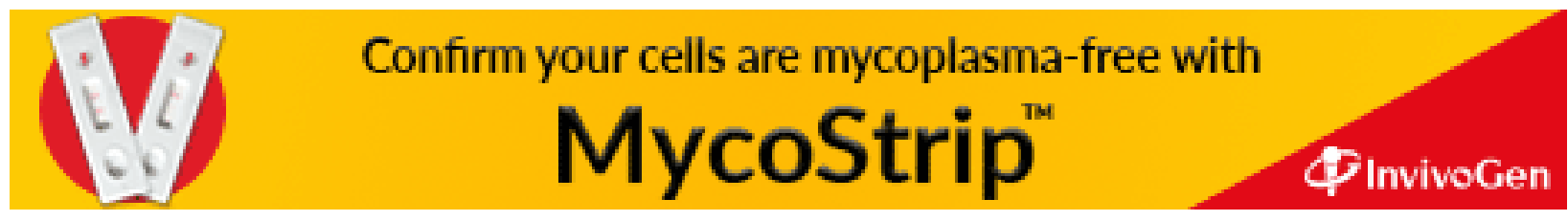

